\title{
Informed Consent and the Dying Patient
}

People afflicted with terminal illness ${ }^{1}$ rarely die at home. The success of medicine has shifted the locus of dying to public and private health care institutions, ${ }^{2}$ thus transferring control over treatment away from the patient and his family to the health care provider and the state. This has been a tacit accommodation to the way health sciences treat the dying, rather than an explicit legal choice.

The terminally ill patient may nevertheless wish to forego treatment offered by the health care institution for a number of reasons: religious beliefs, pain and suffering, exhaustion of financial resources, ${ }^{3}$ acquiescence to death on the loss of control over most bodily functions. The patient's wish may conflict with the interests of the health care providers who are committed to prolongation of life through medical technology, ${ }^{4}$ or with what seem to be the interests of the state, asserted through laws against suicide and homicide. The application of these laws is fraught with difficulty in cases of "passive euthanasia,"s the withholding of life-sustaining medical treatment; none-

1. Since death is inevitable, life itself could be characterized as a terminal illness. This Note necessarily uses "terminal illness" in a more limited sense, to refer to imminent death. Medical science has failed to elucidate the concept beyond this general understanding, and the problems of lucid intervals and remissions in the patient complicate any general definition. $C f$. I W. ANderson, PATHOLOGY 551.52 (6th ed. 1971 ).

2. See E. KüBler-Ross, ON Death and DYing 5-7 (1969); Cassell, Dying in a Technological Society, Hastings Center Studies, May 1974, at 31; Pritchard, "Dying"-Some Issues and Problems, 164 ANNALS N.Y. ACAD. ScI. 707, 711-13 (1969).

3 . There has been some discussion of possible liability of health care providers for delaying death by use of expensive mechanical devices contrary to the will of the patient and his family. See Euthanasia Questions Stir New Debate, MED. Wordd News, Sept. 14, 1973, at 78 .

4. Morison, Dying, Scientific Am., Sept. 1973, at 54; Stevens, Do Patients Ever Have Rights in the Timing of Their Own Death?, 8 New ENc. L. REv. 181 (1973).

5. Two broad types of euthanasia are generally distinguished as applicable to such patients: active (actual rendition of a life-shortening agent), and passive (withholding of a life-sustaining treatment). See To LIVE and To DIE: WHEN, WHY, and How 90 (R. Williams ed. 1973) [hereinafter cited as To LIve AND To DIE]. Four types of euthanasia are distinguished in Fletcher, Ethics and Euthanasia, 73 AM. J. Nursing 670, 673 (1973), in To Live AND To Die 116. On euthanasia, see, e.g., Cantor, $A$ Patient's Decision to Decline Life Saving Medical Treatment: Bodily Integrity Versus Preservation of Life, 26 Rutgers L. REv. 228 (1972); Gurney, Is There a Right to Die?-A Study of the Law of Euthanasia, 3 Cum.-SAM. L. REv. 235 (1972); Morris, Voluntary Euthanasia, 45 WASH. L. REV. 239 (1970). Euthanasia is usually considered in connection with either the ir. revocably unconscious patient, see note 15 infra, or the competent terminal patient requesting some form of life shortening, see, e.g., Morris, supra; Kutner, Due Process of Euthanasia: The Living Will, A Proposal, 44 IND. L.J. 539 (1969).

The term "euthanasia" itself tends to stifle discussion. "Benemortasia" has been coined to circumvent the word's emotional impact. See Hearings on Death with Dignity Before the Senate Special Comm. on Aging, 92d Cong., 2d Sess. 68-70 [hereinafter cited as Hearings on Dying]; cf. Dyck, An Alternative to the Ethic of Euthanasia, in To Live AND To Die 102. 
theless, some courts have not hesitated to enforce the overruling by doctors of a patient's refusal of treatment. ${ }^{6}$ The proper legal outcome, however, is far from settled. ${ }^{7}$

The doctrine of informed consent ${ }^{8}$ offers an established basis for court resolution of the issue. Since Judge Cardozo's opinion in Schloen-

6. See, e.g., Application of President \& Directors of Georgetown College, Inc., 118 U.S. App. D.C. 80,331 F.2d 1000, rehearing denied, 118 U.S. App. D.C. 90, 331 F.2d 1010 , cert. denied, 337 U.S. 978 (1964) (refusal of blood transfusion by Jehovah's Witness overruled); John F. Kennedy Memorial Hosp. v. Heston, 58 N.J. 576, 279 A.2d 670 (1971) (22-year-old Jehovah's Witness compelled to receive a blood transfusion over her objection).

7. See, e.g., In re Brooks' Estate, 32 Ill. 2d 361, 205 N.E.2d 435 (1965) (Jehovah's Witness may refuse blood transfusion, at least where no minor children are involved and there is no clear and present danger to society). In re Osborne, 294 A.2d 372, 374-75 (D.C. App. 1972), which held that a competent adult may refuse a blood transfusion, distinguished earlier cases involving compulsory rendition of medical care to which the patient objected on religious grounds. The court noted that some cases involved comatose patients or other incompetents, while lives of unborn children or the welfare of survivors were at stake in other cases. The court stressed that whether the patient's "current choice is competently maintained" is important, id. at 375. New York's lower courts have reached inconsistent results. Compare Petition of Nemser, 51 Misc. 2d 616, 273 N.Y.S.2d 624 (Sup. Ct. 1966) (judge refused to intervene in a dispute over the treatment of an 80-year-old suffering from gangrene; the patient's apparent refusal of the operation prevailed), with Long Island Jewish-Hillside Med. Center v. Levitt, 73 Misc. 2d 395, 342 N.Y.S.2d 356 (Sup. Ct. 1973) (judge appointed a guardian to consent to an operation on an 84-year-old suffering from gangrene despite a dispute as to his wishes). See also Collins v. Davis, 44 Misc. 2d 622, 254 N.Y.S.2d 666 (Sup. Ct. 1964) (compelling treatment); Erickson v. Dilgard, 44 Misc. 2d 27, 252 N.Y.S.2d 705 (Sup. Ct. 1962) (following patient's wishes); D. Hendin, Death as a Fact of LifE 66.70 (1973) (recounts cases in which patient's decision was upheld in Wisconsin and denicd in New York).

8. See generally Plante, An Analysis of "Informed Consent," 36 FordhaM L. REv. 639 (1968); Waltz \&: Scheuneman, Informed Consent to Therapy, 64 Nw. U.L. REv. 628 (1970); Note, Restructuring Informed Consent: Legal Therapy for the Doctor-Patient Relationship, 79 Yale L.J. 1533 (1970). See also 119 Cong. Rec. S16335-36 (daily ed. Sept. 11, 1973).

The doctrine of informed consent has not been recognized by appellate courts in all American jurisdictions. See, e.g., Martin v. Stratton, 515 P.2d 1366, 1369-70 (Okla. 1973). In addition, the feasibility of informed consent has been questioned. See Fellner \& Marshall, Kidney Donor-The Myth of Informed Consent, 126 AM. J. PsYcH. 1245-51 (1970).

The Department of Health, Education, and Welfare recently promulgated regulations governing grants and contracts supporting research involving human subjects. They include the following definition of informed consent:

"Informed consent" means the knowing consent of an individual or his legally authorized representative, so situated as to be able to exercise free power of choice without undue inducement or any element of force, fraud, deceit, duress or other form of constraint or coercion. The basic elements of information necessary to such consent include:

(1) A fair explanation of the procedures to be followed, and their purposes, including identification of any procedures which are experimental;

(2) a description of any attendant discomforts and risks reasonably to be expected;

(3) a description of any benefits reasonably to be expected;

(4) a disclosure of any appropriate alternative procedures that might be advantageous for the subject;

(5) an offer to answer any inquiries concerning the procedures; and

(6) an instruction that the person is free to withdraw his consent and to discontinue participation in the project or activity at any time without prejudice to the subject.

39 Fed. Reg. 18917 (1974). 
dorff $v$. Society of New York Hospital, ${ }^{9}$ courts have, in nonterminal cases, $^{10}$ regularly premised ${ }^{11}$ the doctrine on the basic principle that "[e]very human being of adult years and sound mind has a right to determine what shall be done with his own body ...."12 This axiom has been restated recently in the leading case of Natanson $v$. Kline ${ }^{13}$ as follows:

Anglo-American law starts with the premise of thorough-going self-determination. It follows that each man is considered to be master of his own body, and he may, if he be of sound mind, expressly prohibit the performance of life-saving surgery, or other medical treatment. A doctor might well believe that an operation or form of treatment is desirable or necessary but the law does not permit him to substitute his own judgment for that of the patient by any form of artifice or deception. ${ }^{14}$

While purporting to apply the basic principle, however, courts in different jurisdictions have developed a wide variety of formulations that inhibit realization of ultimate control by the patient. When a court focuses on the doctor's therapeutic privilege to withhold information or bases its determination of the doctor's liability on the disclosure standards observed by the local medical community, the patient's self-determination may be too easily overlooked.

This Note argues that, in accordance with the postulate of selfdetermination, someone other than the health care provider should set the standard and scope of disclosure. Courts should scrutinize with care any accretions to the doctrine of informed consent that diminish the information a patient receives or that circumscribe his entitlement to consent before treatment. The stress some courts place on interests countervailing the Schloendorff axiom may represent an implicit questioning of the validity of that principle. However, this Note contends that probing the underpinnings of the principle will reveal even more fundamental interests which require results consistent with

9. 211 N.Y. 125, 105 N.E. 92 (1914), overruled on other grounds, Bing v. Thunig, 2 N.Y.2d 656, 143 N.E.2d 3, 163 N.Y.S.2d 3 (1957) (immunity for charitable hospitals rejected).

10. The principle has been noted in some terminal cases as well. See, e.g., Long Island Jewish-Hillside Med. Center v. Levitt, 73 Misc. 2d 395, 397-98, 342 N.Y.S.2d 356, 359 (Sup. Ct. 1973).

11. Schloendorff v. Society of N.Y. Hosp., 211 N.Y. 125, 129, 105 N.E. 92, 93 (1914)

12. See, e.g., Canterbury v. Spence, 150 U.S. App. D.C. 263, 271, 464 F.2d 772, 780, cert. denied, 409 U.S. 1064 (1972); Cobbs v. Grant, 8 Cal. 3d 229, 242, 502 P.2d 1, 9, 104 Cal. Rptr. 505, 513 (1972); Collins v. Itoh, 503 P.2d 36, 40 (Mont. 1972); Congrove v. Holmes, 308 N.E.2d 765, 769, 771 (C.P. Ross Co., Ohio 1973); Wilkinson v. Vesey, 110 R.I. 606, 619, 295 A.2d 676, 685 (1972); Trogun v. Fruchtman, 58 Wis. 2d 569, 596 n.30, 207 N.W.2d 297, 311 n.30 (1973).

13. 186 Kan. 393,350 P.2d 1093, rehearing denied, 187 Kan. 186, 354 P.2d 670 (1960).

14. Id. at $406-07,350$ P.2d at 1104 . 
the axiom in those cases in which the courts engage in some variety of balancing.

Viewed in this light, the doctrine of informed consent requires that any competent patient should retain control over decisions about treatment, even if he is suffering from a terminal illness. ${ }^{15}$ This Note will explore the implications of informed consent for types of voluntary euthanasia. ${ }^{16}$ Most of the implications will suggest guidelines for appropriate judicial results, but the solution to the euthanasia problem may well require legislative changes ${ }^{17}$ to minimize conflict with present homicide and suicide laws.

\section{Informed Consent}

The doctrine of informed consent emerged from medical malpractice cases involving rendition of some treatment to which the patient had not consented. ${ }^{18}$ Treatment necessarily involves a touching of the patient's body. If performed without a valid consent, it has been viewed as an intentional ${ }^{19}$ interference with the person-a battery. ${ }^{20}$ Expert

15. Thus, this Note is concerned only with voluntary forms of euthanasia, and not with the problem of brain death (an alternative definition of death based on irrevocable unconsciousness) or any definition of death for purposes of involuntary euthanasia. Proponents of brain death have met with some success in legislatures, see Kan. STat. ANN. $\$ 77.202$ (Supp. 1973), criticized in Capron and Kass, A Statutory Definition of the Standards for Determining Human Death: An Appraisal and a Proposal, 121 U. PA. L. REv. 87, 108-11 (1972); Mb. ANN. Cone art. 43, $\$$ 54F (Cum. Supp. 1973). Brain death has also received some acceptance in the courts. Kennedy, The Legal Definition of Death, 41 Medico-Legal J. 36 (1973) (discusses Virginia case). Cf. Calabresi, Birth, Death, and the Law, 37 Pharos 39 (1974); Dworkin, Death in Context, 48 IND. L.J. 623 (1973).

16. Most writers have not viewed the doctrine of informed consent as central to the case for euthanasia, see, e.g., Note, Legal Aspects of Euthanasia, 36 ALr. L.J. 674, 685.86 (1972), but a few have mentioned it, see, e.g., Survey, Euthanasia: Criminal, Tort, Constitutional and Legislative Considerations, 48 NoTre Dame LAw. 1202, 1218-24 (1973).

17. Examples of recently proposed legislation legalizing passive euthanasia include Fla. S.B. 253 (1973 Reg. Sess.); Fla. H.B. 407 (1973 Reg. Sess.); Ore. H.B. 2997 (1973 Reg. Sess.). Active euthanasia would be permitted under Ore. S.B. 179 (1973 Reg. Sess.).

Ore. S.B. 179 (active euthanasia) received a "very rough" reception from the newspapers and from letters by the general public. The bill was withdrawn as a result. Ore. H.B. 2997 (passive euthanasia) died in committee despite amendments by Governor McCall's legal staff and the assistance of the Medical Society lobby. Letter from State Senator C.R. Hoyt to Charles H. Montange, Mar. 20, 1974 (on file with the Yale Law Journal).

The Florida bills will apparently be reintroduced for further consideration by the Florida legislature. However, opponents have prepared memorials to Congress encouraging passage of a constitutional amendment apparently intended to overrule Roe $v$. Wade, 410 U.S. 113 (1973) (legalizing abortions), and perhaps also to prohibit both active and passive euthanasia, even if voluntary. Fla. S. Mem. 162 and H. Mem. 2677 (1974 Reg. Sess.).

18. See, e.g., Pratt v. Davis, 118 Ill. App. 161, 166, aff'd, 224 IIl. 300, 79 N.E. 562 (1906).

19. The intent need not be malicious. "Rather it is an intent to bring about a result which will invade the interests of another in a way that the law will not sanction." W. Prosser, HandBook of THE LAW OF TORTS 31 (4th ed. 1971).

20. See, e.g., Mohr v. Williams, 95 Minn. 261, 270-71, 104 N.W. 12, $15-16$ (1905), overruled on other grounds, Genzel v. Halvorson, 248 Minn. 527, 80 N.W.2d 854 
testimony as to the standard medical community practice is not required in a battery action, ${ }^{21}$ since liability is not based on any standard of care but rather on an unlawful touching. ${ }^{22}$ For situations in which the doctor performs a treatment for which no consent whatsoever has been obtained, battery is the appropriate theory for recovery in many jurisdictions. ${ }^{23}$

However, in situations in which the patient consents to a treatment but an undisclosed risk materializes, courts have been reluctant to find that the physician has committed an intentional tort. ${ }^{24}$ In such cases, physicians have generally been allowed to interpose the defense that disclosure of the risk in question was not customary in the local medical community. ${ }^{25}$ This encouraged some courts to view insufficient disclosure of risks and alternatives as a failure to exercise due care. ${ }^{26} \mathrm{~A}$ due care standard is doctrinally more consistent with negligence than with battery; therefore a trend has developed to view failure to obtain an informed consent as a tort of negligence. ${ }^{27}$

\section{A. Information and Consent}

Whether battery or negligence is the theory, ${ }^{28}$ informed consent involves the two vital elements its name implies: the patient must be given information on the risks involved in the treatment, and he must assent to the treatment. ${ }^{29}$ The fiduciary relationship between the doc-

(1957); Schloendorff v. Society N.Y. Hosp., 211 N.Y. 125, 129, 105 N.E. 92, 93 (1914); cf. Fogal v. Genesee Hosp., 41 App. Div. 2d 468, 473, 344 N.Y.S.2d 552, 559 (1973); W. Prosser, supra note 19, at 105-06, 165.

21. See, e.g., Bang v. Charles T. Miller Hosp., 251 Minn. 427, 88 N.W.2d 186 (1958) (vasectomy performed without patient's consent); Fogal v. Genesee Hosp., 41 App. Div. 2d 468, 344 N.Y.S.2d 552 (1973) (informed consent is a battery action in New York; proof of community standard is not necessary).

22. Cobbs v. Grant, 8 Cal. 3d 229, 240, 502 P.2d 1, 8, 104 Cal. Rptr. 505, 512 (1972) (dictum). In addition, the doctor could be held for punitive damages if guilty of battery. But cf. Trogun v. Fruchtman, 58 Wis. 2d 569, 600, 207 N.W.2d 297, 313 (1973).

23. See, e.g., Canterbury v. Spence, 150 U.S. App. D.C. 263, 274, 464 F.2d 772, 783, cert. denied, 409 U.S. 1064 (1972); Berkey v. Anderson, 1 Cal. App. 3d 790, 803, 82 Cal. Rptr. 67, 76-77 (1969); Wilkinson v. Vesey, 110 R.I. 606, 621, 295 A.2d 676, 686 (1972).

24. See, e.g., Cobbs v. Grant, 8 Cal. 3d 229, 240-41, 502 P.2d 1, 8, 104 Cal. Rptr. $505,512(1972)$.

25. Id.; Karp v. Cooley, 349 F. Supp. 827, 834 (S.D. Tex. 1972) (both "school" and "medical community" standards applicable in Texas in action based on heart surgery).

26. Cobbs v. Grant, 8 Cal. 3d 229, 243, 502 P.2d 1, 8, 104 Cal. Rptr. 505, 514 (1972); W. Prosser, supra note 19 , at 165 .

27. See, e.g., Cobbs v. Grant, 8 Cal. 3d 229, 243, 502 P.2d 1, 8, 104 Cal. Rptr. 505, 514 (1972); Wilkinson v. Vesey, 110 R.T. 606, 626, 295 A.2d 676, 686 (1972) (collects the cases).

28. While most jurisdictions apparently categorize informed consent as either negligence or battery, Ohio views the cause of action as valid under both theories. Belcher v. Carter, 13 Ohio App. 2d 113, 114, 234 N.E.2d 311, 312 (1967).

29. See Waltz \&. Scheuneman, supra note 8, at 630; cf. Wilkinson v. Vesey, 110 R.I. $606,628,295$ A.2d 676, 688 (1972).

Some commentators stress a third vital element: The patient must comprehend the information which has been conveyed. See Ingelfinger, Informed (But Uneducated) Con- 
tor and patient obligates the doctor to assure the presence of both elements before undertaking a procedure. ${ }^{30}$

However, risks which are everyday knowledge need not be mentioned to the patient, ${ }^{31}$ and disclosure of "material" risks is sufficient..$^{32}$ Furthermore, physicians will be held responsible for revealing only such risks as are known to reasonably prudent comparable practitioners. ${ }^{33}$ However, courts adopting a negligence theory for informed consent differ greatly over what constitutes a material risk.

The view accepted by the majority of American jurisdictions bases the duty to disclose on a community standard; it requires only such disclosure of risks as is consistent with the practice of the local medical community. ${ }^{34}$ Expert medical testimony is required to show a breach of local medical standards. ${ }^{35}$ The majority rule results from a

sent, 287 NEW ENG. J. MED. 465 (1972). For a recent proposal to increase comprehension, see Miller \& Willner, $A$ Suggestion for Promoting Free and Informed Consent, 290 NEW ENG. J. MED. 964 (1974). Judicial development of this element will probably occur after the notions of "information" and "consent" are more settled, although the im. portance of comprehension has been recognized. See Canterbury v. Spence, 150 U.S. App. D.C. 263, 271 nn.14-15, 464 F.2d 772, 780 nn.14-15, cert. denied, 409 U.S. 1064 (1972).

30. Cobbs v. Grant, 8 Cal. 3d 229, 246, 502 P.2d 1, 10, 104 Cal. Rptr. 505, 515 (1972); Natanson v. Kline, 186 Kan. 393, 401, 350 P.2d 1093, 1101, rehearing denied, 187 Kan. 186, 354 P.2d 670 (1960).

31. Wilkinson v. Vesey, 110 R.I. 606, 629, 295 A.2d 676, 689 (1972). See Shetter v. Rochelle, 2 Ariz. App. 358, 369, 409 P.2d 74, 85 (1965) (reasonable people know some risks exist in delicate operation).

32. Getchell v. Mansfield, 260 Ore. 174, 489 P.2d 953 (1971); Wilkinson v. Vesey, 110 R.I. 606, 629, 295 A.2d 676, 689 (1972); ZeBarth v. Swedish Hosp. Med. Center, 81 Wash. 2d 12, 25, 499 P.2d 1, 9-10 (1972).

33. See Riedinger v. Colburn, 361 F. Supp. 1073, 1076-77 (D. Idaho 1973) (orthopedic surgeon testified to no personal knowledge of such a risk as materialized and introduced studies indicating it was "virtually unknown"); Cobbs v. Grant, 8 Cal. 3d 229, 244. 502 P.2d 1, 11, 104 Cal. Rptr. 505, 515 (1972); cf. Karriman v. Orthopedic Clinic, 516 P.2d 534 (Okla. 1973). Thus, a physician must know, according to a medical community standard, the risks and alternatives attendant on a proposed procedure.

34. See, e.g., Shetter v. Rochelle, 2 Ariz. App. 358, 370, 409 P.2d 74, 86 (1965); Stauffer v, Karabin, 492 P.2d 862, 865 (Colo. App. 1971); DiFilippo v. Preston, 53 Del. 539, 550, 173 A.2d 333, 339 (1961); Grosjean v. Spencer, 258 Iowa 685, 694, 140 N.W.2d 139, 145 (1966); Collins v. Itoh, 503 P.2d 36, 41 (Mont. 1972); ZeBarth v. Swedish Hosp. Med. Center, 81 Wash. 2d 12. 24-26. 499 P.2d 1, 9-10 (1972); Watkins v. Parpala, 2 Wash. App. 484, 489, 469 P.2d 974, 979 (1970).

35. Grosjean v. Spencer, 258 Iowa 685, 694, 140 N.W.2d 139, 145 (1966); Marchlewicz v. Stanton, 213 N.W.2d 317, 319 (Mich. App. 1973) (no jury question if expert testimony is not produced). The majority view espoused by Michigan was apparently departed from in a lower court decision involving psychosurgery. See Note, Kaimowitz v. Department of Mental Health: A Right to Be Free from Experimental Psychosurgery?, 54 B.U. L. REv. 301,317 (1974). See also Perin v. Hayne, 210 N.W.2d 609 (Iowa 1973) (court left open the informed consent issue since the plaintiff had offered no evidence as to causation; however, citations to Canterbury v. Spence, 150 U.S. App. D.C. 263, 464 F.2d 772, cert. denied, 409 U.S. 1064 (1972), and Cobbs v. Grant, 8 Cal. 3d 229, 502 P.2d 1, 104 Cal. Rptr. 505 (1972), suggest that the court might entertain abandonment of the old rule requiring expert testimony on the duty to disclose if the question is properly presented). From Natanson v. Kline, 186 Kan. 393, 350 P.2d 1093, rehearing denied, 187 Kan. 186, 354 P.2d 670 (1960), to Collins v. Meeker, 198 Kan. 390, 424 P.2d 488 (1967), the Kansas rule seemed to be that a patient need not submit expert testimony regarding standards for disclosure. However, if the doctor did submit such testimony, then the patient had to rebut. Kansas currently limits the duty to inform to those 
view of the fiduciary relationship between physician and patient that perceives the doctor's duty to disclose as subservient to his general duty "to do what is best" for the patient. ${ }^{38}$ The latter duty is a function of the local medical community standard which must be established by expert testimony. ${ }^{37}$ Since the obligation to disclose is seen as part of, or subservient to, the more general duty, the standard of disclosure is described as a question of medical judgment. Thus no disclosure is required unless expert testimony indicates that otherwise the relevant standard of medical care would be breached. ${ }^{38}$

This view, however, threatens to emasculate the individual self-determination which the doctrine of informed consent was meant to protect. ${ }^{39}$ The patient's right to select treatment is severely limited when it is based only on information deemed worthy of disclosure according to a medical community standard set by those under the obligation to inform. ${ }^{40}$ Thus the medical community standard test runs contrary to vesting ultimate determination of treatment questions in the patient and diminishes rather than assures his self-determination. ${ }^{41}$ Furthermore, it is open to abuse. It may be used as a de-

disclosures which a "reasonable physician" would make, Funke v. Fieldman, 512 P.2d 539, 546 (Kan. 1973), citing Tatro v. Lueken, 512 P.2d 529 (Kan. 1973). This duty depends on the facts of each case. Thus, a community standard is not explicitly mentioned, but may enter in determining what a "reasonable physician" would do. However, Funke indicates that a "reasonable physician" may on no account be misleading, $512 \mathrm{P} .2 \mathrm{~d}$ at 548 .

36. Difilippo v. Preston, 53 Del. 539, 550, 173 A.2d 333, 339 (1961); Grosjean v. Spencer, 258 Iowa 685, 693-94, 140 N.W.2d 139, 144-45 (1966).

37. Grosjean v. Spencer, 258 Iowa 685,140 N.W.2d 139 (1966).

38. See, e.g., Roberts v. Young, 369 Mich. 133, 119 N.W.2d 627 (1963); Aiken v. Clary, 396 S.W.2d 668 (Mo. 1965). The traditional medical malpractice test is in terms of the degree of skill ordinarily possessed by physicians and surgeons practicing in similar localities. Ferrell v. Ellis, 129 Iowa 614, 105 N.W. 993 (1906). But cf. McGulpin v. Bessmer, 241 Iowa 1119, 43 N.W.2d 121 (1950) (specialist held to higher standard). But increasingly, experts from other localities are permitted to testify as to accepted medical standards. See, e.g., Brune v. Belinkoff, 354 Mass. 102, 235 N.E.2d 793 (1968). A more general medical community standard secms to be supplanting the old locality rule. Several rationales have been offered for the majority rule applying a community standard to disclosure. One court mentioned a desire to encourage experimentation. Watkins $v$. Parpala, 2 Wash. App. 484, 489, 469 P.2d 974, 979 (1970). Another rationale is to protect physicians from excessive liability. Note, Informed Consent-A Proposed Standard for Medical Disclosure, 48 N.Y.U. L. REv. 548, 554 (1973). Further, there is some feeling that because "[ $t]$ he layman would have no conception of the complex nature of the problem," disclosure is unnecessary, Sinkey v. Surgical Associates, 186 N.W.2d 658, 662 (Iowa 1971). Some courts even argue that the rule is necessary to avoid upsetting or driving away patients. Stauffer v. Karabin, 492 P.2d 862 (Colo. App. 1971); Nishi v. Hartwell, 52 Hawaii 188, 473 P.2d 116 (1970).

39. Natanson v. Kline, 186 Kan. 393, 407, 350 P.2d 1093, 1104, rehearing denied, 187 Kan. 186, 354 P.2d 670 (1960); Schloendorff v. Society of N.Y. Hosp., 211 N.Y. 125, 129-30, 105 N.E. 92, 93 (1914). See 2 F. HARPER \& F. JAMES, The LAw of TorTs 61 (Supp. 1968).

40. Mason v. Ellsworth, 3 Wash. App. 298, 308, 474 P.2d 909, 916 (1970).

41. An objective medical community standard of disclosure may not exist or may be excessively difficult to establish due to the complexities of each case. Wilkinson $v$. Vesey, 110 R.I. 606, 623-24, 295 A.2d 676, 687 (1972), citing Note, Informed Consent in Medical Malpractice, 55 CALIF. L. REv. 1396 (1967). See also Mason v. Ellsworth, 3 Wash. App. 298, 311 n.11, 474 P.2d 909, 918 n.11 (1970), citing 75 HARv. L. REv. 1445, 1447 
vice either to conceal information which might cause the patient to forego treatment, ${ }^{42}$ or to avoid possible confrontations with patients and their families which might be emotionally difficult for the patient or doctor. ${ }^{43}$

In recent years, courts in several jurisdictions ${ }^{44}$ have recognized these objections and have abolished the medical community standard, adopting new tests for disclosure. Seeking to retain some limits on physician liability, the new tests utilize a reasonable man standard. However, they apply the standard to differing elements of the case. One scheme applies the reasonable man test to materiality of the information withheld. ${ }^{45}$ Another applies the test to causation and appears to leave materiality to a more subjective standard. ${ }^{40}$ Yet another formulation weighs both materiality and causation according to an objective test. ${ }^{47}$

The Rhode Island Supreme Court in Wilkinson v. Vesey ${ }^{48}$ con-

(1962). There is a more pragmatic objection to the majority view: It requires plaintiffs to present expert witnesses, who are difficult to produce because of the professional "conspiracy of silence" concerning malpractice. Cooper v. Roberts, $220 \mathrm{~Pa}$. Super. 260, 286 A.2d 647 (1971).

42. See ZeBarth v. Swedish Hosp. Med. Center, 81 Wash. 2d 12, 25-26, 499 P.2d 1, $9-10$ (1972) stating that "[ $t]$ he doctrine of informed consent does not require the doctor to risk frightening the patient out of a course of treatment which sound medical judgment dictates the patient should undertake."

43. See Davis, Uncertainty in Medical Prognosis, Clinical and Functional, 66 AM. J. Soc. 41 (1960). Davis reports that, in order to avoid confrontations, parents of children stricken with polio were not told of the prognosis which the physicians had reached. The physician in Congrove v. Holmes, 308 N.E.2d 765, 768 (C.P. Ross Co., Ohio 1973), did not reveal risks of surgery. He stated that if he revealed "even half the complications .... many people would refuse to have anything done and, therefore, would be worse off." The court rejected the physician's position. See also Tatro v. Lueken, 512 P.2d 529, 537 (Kan. 1973).

Some evidence indicates that such concealment is not desirable therapeutically. I. JANIs, Psychological Stress-Psychoanalytic and Behavioral Studies of Surgical Patients $352-53,367-71$ (1958).

44. California: Cobbs v. Grant, 8 Cal. 3d 229, 502 P.2d 1, 104 Cal. Rptr. 505 (1972); District of Columbia: Canterbury v. Spence, 150 U.S. App. D.C. 263,464 F.2d 772, cert. denied, 409 U.S. 1064 (1972); New Mexico: Woods v. Brumlop, 71 N.M. 221, 377 P.2d 520 (1962); New York: Fogal v. Genesee Hosp., 41 App. Div. 2d 468, 344 N.Y.S. 2d 552 (1973); Oregon: Getchell v. Mansfield, 260 Ore. 174, 489 P.2d 953 (1971); Rhode Island: Wilkinson v. Vesey, 110 R.I. 606, 295 A.2d 676 (1972); Wisconsin: Trogun v. Fruchtman, 58 Wis. 2d 569, 207 N.W.2d 297 (1973). No controlling state court decisions exist in Idaho, but a federal district court sitting in diversity followed Cobbs. See Riedinger v. Colburn, 361 F. Supp. 1073, 1076-77 (D. Idaho 1973). A lower court in Ohio has rejected the community standard rule, Congrove v. Holmes, 308 N.E.2d 765, 771 (C.P. Ross Co., Ohio 1973). While lower Washington courts had divided on this issue, compare Mason v. Ellsworth, 3 Wash. App. 298, 474 P.2d 909 (1970); Hunter v. Brown, 4 Wash. App. 899, 484 P.2d 1162 (1971) (against the community standard rule), with Watkins v. Parpala, 2 Wash. App. 484,469 P.2d 974 (1970) (for the rule), the state's highest court decided to retain the rule, ZeBarth v. Swedish Hosp. Med. Center, 81 Wash. 2d 12, 499 P.2d 1 (1972). But cf. Helling v. Carey, 519 P.2d 981 (Wash. 1974).

45. Wilkinson v. Vesey, 110 R.I. 606, 627, 295 A.2d 676, 689 (1972).

46. Cobbs v. Grant, 8 Cal. 3d 229, 243.45, 502 P.2d 1, 10-12, 104 Cal. Rptr. 505, 514-16 (1972).

47. Canterbury v. Spence, 150 U.S. App. D.C. 263, 278, 282, 464 F.2d 772, 787, 791, cert. denied, 409 U.S. 1064 (1972).

48. 110 R.I. 606,295 A.2d 676 (1972). 
cluded that the patient must be given all material information necessary for a decision. The character of material information could not be determined by a "local medical group" which has no knowledge of the individual or the unique situation involved. ${ }^{49}$ The court reasoned that the decision as to materiality is a human judgment which does not require expert medical testimony, but may be determined by the jury. ${ }^{50}$ Disclosure should extend to all facts which a reasonable man would regard as material ${ }^{51}$ in light of the severity of the risk and the likelihood of its occurrence-the more severe or likely the risk, the more probable that it is material..$^{52}$

Wilkinson also discussed causation. To recover in a malpractice action for lack of informed consent, the patient must show not only that the physician failed to disclose a material fact, but also that he, the patient, would have refused consent had he been informed of the fact, and that he has been injured as a result of the concealment. ${ }^{.3}$ The focus is on what the particular patient would have done, thus wisely making the causation test more subjective than the materiality requirement.

49. The court notes that the basis of informed consent is "the patient's right to be the final judge to do with his body as he wills." This right "should not be delegated to a local medical group." Id. at $625,295 \mathrm{~A} .2 \mathrm{~d}$ at 688 .

50. Wilkinson v. Vesey, 110 R.I. 606, 626, 295 A.2d 676, 688 (1972). The patient must still submit expert testimony to establish the known risks, but the jury determines what is material. The court provided that the doctor may still adduce evidence as to the existence of community standards.

51. Wilkinson v. Vesey, 110 R.I. 606, 628, 295 A.2d 676, 689 (1972). The court also reasoned that no disclosure was necessary if "it would unduly agitate or undermine an unstable patient." 110 R.I. at 628,295 A.2d at 689 . However, the criteria for adjudging a patient unstable were not presented, nor was there any suggestion whether competence or stability would be presumed, or whether the doctor or the patient must prove that competence was or was not present.

Canterbury v. Spence, 150 U.S. App. D.C. 263, 278, 464 F.2d 772, 787, cert. denied, 409 U.S. 1064 (1972), noted that the ideal rule governing disclosure would require revelation of all risks which the patient would feel material. However, such a subjective rule was felt by the court to place an "undue demand" on the doctor to "second-guess" the patient.

52. The test is thus similar to that of Canterbury v. Spence, 150 U.S. App. D.C. 263, 278-79, 464 F.2d 772, 787-88, cert. denied, 409 U.S. 1064 (1972). See also Getchell v. Mansfield, 260 Ore. 174, 180, 489 P.2d 953, 956 (1971). The focus on magnitude of risk and likelihood of occurrence of risks perceived by the reasonable man would appear to make the test sufficiently clear to put the physician on notice as to the necessary disclosure. But see Note, supra note 38.

53. The court implies approval of a subjective causation test by citing the sub. jective testimony offered. Wilkinson v. Vesey, 110 R.I. 606, 629 n.12, 295 A.2d 676, 690 n.12 (1972). Generally, to show causation, one must prove that the patient would have refused consent, though courts often do not indicate whether the standard is objective (reasonable man) or subjective (individual). See, e.g., Shetter v. Rochelle, 2 Ariz. App. 358, 409 P.2d 74 (1965); Cobbs v. Grant, 8 Cal. 3d 229, 502 P.2d 1, 104 Cal. Rptr. 505 (1972); Funke v. Fieldman, 512 P.2d 539, 548-49 (Kan. 1973). But see Congrove v. Holmes, 308 N.E.2d 765 (C.P. Ross Co., Ohio 1973). For an objective test of the patient's refusal, see Canterbury v. Spence, 150 U.S. App. D.C. 263, 282, 464 F.2d 772, 791, cert. denied, 409 U.S. 1064 (1972). 
However, Wilkinson unduly restricted recovery to cases in which the patient would have refused treatment altogether. The rule should be broader. If the patient shows that, had he been warned, he would have delayed consent in order to attend to personal or business matters, $^{54}$ he should recover for damages ${ }^{55}$ which he can prove resulted from the concealment. Such a modified rule would be consistent with the requirement of causation for tort liability, ${ }^{56}$ while increasing the scope of protection consistently with the reasons for informed consent. ${ }^{.57}$

The California Supreme Court in Cobbs v. Grant ${ }^{58}$ also began with the familiar postulate of self-determination over one's body as the basis for requiring that the physician disclose to his patient "all information relevant to a meaningful decisional process." 59 This court, rejecting the community standard rule as "overbroad" and "nebulous," opted for a standard more protective of patient's rights. Cobbs required that known risks of death or serious bodily harm be disclosed. The test for adequate disclosure is the patient's need for information,

54. Failure to disclose based on a purported community standard may prevent patients from ordering their affairs to meet contingencies. Cobbs v. Grant, 8 Cal. 3d 229, 243, 502 P.2d 1, 10, 104 Cal. Rptr. 505, 514 (1972) (information essential to chart course knowledgeably). For example, in Grosjean v. Spencer, 258 Iowa 685, 140 N.W.2d 139 (1966), the patient consented to an operation with the understanding that he would be home before Christmas. Undisclosed but foreseeable complications resulted in his death. Had the risks been disclosed, the patient might well have delayed the operation.

55. The measure of damages in an informed consent tort action has not received extensive appellate attention. See Waltz \& Scheuneman, supra note 8, at 648. Natanson v. Kline, 186 Kan. $393,411,350$ P.2d 1093, 1107, rehearing denied, 187 Kan. 186, 354 P.2d 670 (1960) (dictum), treats failure to obtain informed consent as a breach of duty which results in liability in damages for any undisclosed risk that materializes, whether or not the therapy was otherwise nonnegligently performed. Waltz \& Scheuneman, supra note 8 , at 649 , criticize this position as allowing an unjustifiably large recovery in cases which really involve no malpractice, and propose that damages should be the difference between the patient's condition with no treatment (or alternative treatment if such is available) and his condition after the risk materialized. Since valuation could well be difficult if alternatives are available, they suggest that the Natanson test may be employed in such cases. However, failure to obtain an informed consent itself constitutes malpractice. Failure to inform is increasingly viewed as a breach of duty creating a tort in negligence. Trogun v. Fruchtman, 58 Wis. 2d 569, 597, 207 N.W.2d 297, $312-13$ (1973). If informed consent actions are otherwise treated as malpractice cases, the measure of damages should also be the malpractice measure: the damage resulting from the breach of duty. In informed consent cases, the breach of duty is the failure to inform. The damage is the materialized undisclosed risk which the patient could not avoid because he was not informed. See Funke v. Fieldman, 512 P.2d 539, 549 (Kan. 1973). Natanson has been followed in Demers v. Gerety, 515 P.2d 645, 650 (N.M. Ct. App. 1973) (dictum); and ZeBarth v. Swedish Hosp. Med. Center, 81 Wash. 2d 12, 27, 499 P.2d 1, 10 (1972) (dictum). Requiring a patient to show that he would have been better off undergoing alternative treatment would in many cases introduce highly speculative considerations into the damage proofs.

56. See W. Prosser, supra note 19 , at 236.

57. See pp. 1643-47 infra.

58. 8 Cal. 3d 229, 502 P.2d 1, 104 Cal. Rptr. 505 (1972).

59. Id. at 242, 502 P.2d at 9-10, 104 Cal. Rptr. at 513 (1972). 
a need which encompasses "whatever is material to the decision." 00 The California decision leaves materiality undefined, and is unclear whether an objective test as in Wilkinson is to be employed, or whether a subjective test based on the individual patient is intended. The probable explanation for the lack of clarity is that the Cobbs court was avoiding the materiality issue by concentrating on causation. ${ }^{61}$ In order to prevent what it saw as a risk of excessive liability for physicians as a result of the patient's questionable hindsight, the court established an objective test for causation: The doctor is liable only if the trier of fact decides that a reasonable man in the patient's position would have refused treatment when adequately informed. ${ }^{62}$

This causation test is inappropriate in informed consent cases. The California court should have applied the objective test only to determine the required scope of disclosure-the materiality issue-as the Rhode Island court did. ${ }^{63}$ The doctor should be held responsible only for disclosing risks a reasonable man would deem material. ${ }^{64}$ If a more subjective standard forcing the doctor to guess at the need to disclose reasonably immaterial risks were adopted, his liability would be dependent on the vagaries of each patient's desire for information. ${ }^{05}$ However, once a fact has been found objectively material, the patient should be allowed recovery if he can show that he would have refused treatment, even unreasonably. ${ }^{66}$ In other words, the test of causation should be more subjective. ${ }^{67}$ This individualized test of causation is indicated because informed consent seeks to assure patients the right to make even irrational decisions. Therefore, the patient's act of refusal cannot be weighed by an objective or reasonable man test, nor need it be, since nondisclosure of a material risk is the central element.

Wilkinson properly isolates and concentrates with an objective test on the question of materiality. Cobbs likewise is a step in the right direction for it abolishes the community standard as to what risks will

60. Id. at 245,502 P.2d at 11,104 Cal. Rptr. at 515 (1972).

61. Such an approach is favored in Note, supra note 38 , at 553 .

62. Cobbs v. Grant, 8 Cal. 3d 229, 245, 502 P.2d 1, 11-12, 104 Cal. Rptr. 505, 515-16

(1972). See also Funke v. Fieldman, 512 P.2d 539, 549-50 (Kan. 1973).

63. See pp. 1639-41 supra.

64. See Waltz \& Scheuneman, supra note 8, at 610; Wilkinson v. Vesey, 110 R.I. 606, 627, 295 A.2d 676, 689 (1972).

65. The physician should be held responsible for disclosing only those facts known by reasonably prudent comparable practitioners. See note 33 supra. This is, of course, a significant restriction on liability.

66. 2 F. HARPER \& F. JAMES, supra note 39 , at 61 .

67. The California court does suggest an awareness of this at one point: "The weighing of these risks against the individual subjective fears and hopes of the patient is not an expert skill. Such evaluation and decision is a nonmedical judgment reserved to the patient alone." Cobbs v. Grant, 8 Cal. 3d 229, 243, 502 P.2d 1, 10, 104 Cal. Rptr. 505, 514 (1972). 
be deemed significant. However, Cobbs fails to arrive at a clear test of materiality, for it sidesteps the issue by establishing an objective causation test, thereby undercutting the basic reasons for informed consent. .8 $^{6}$

\section{B. Underpinnings of the Doctrine}

Judicial deviation from the basic principle of informed consentself-determination over one's own body ${ }^{69}$-perhaps results from a failure to probe the underpinnings of that axiom. ${ }^{70}$ The principle implies that there exist categories of decisions which an individual must be permitted to make, even if others believe the individual decides irrationally or incorrectly. ${ }^{71}$ It indicates that an implicit weighing of the interests of competing decisionmakers has already taken place and that the balance has been resolved in favor of individual choice. ${ }^{2}$ Courts and commentators may analyze the class of decisions reserved to the individual to rest on John Stuart Mill's concept of freedom of choice over matters which have a direct adverse effect ${ }^{73}$ on no one but

68. Regarding the Cobbs causation problem, see Comment, Informed Consent After Cobbs-Has the Patient Been Forgotten?, 10 San Drego L. Rev. 913, 924-26 (1973).

The California test also involves possible liability for nondisclosure beyond the minimal mandatory requirement of revelation of material risks. The court suggested that doctors would also be liable for failure to reveal such other risks as physicians in good standing would disclose. Cobbs v. Grant, 8 Cal. 3d 229, 245, 502 P.2d 1, 11, 104 Cal. Rptr. 505, 515 (1972). Thus a community standard is maintained for "minor" or insignificant risks.

69. See Schloendorff v. Society of N.Y. Hosp., 211 N.Y. 125, 129-30, 105 N.E. 92, 93 (1914); Cobbs v. Grant, 8 Cal. 3d 229, 242, 502 P.2d 1, 9, 104 Cal. Rptr. 505, 513 (1972).

70. See, e.g., Natanson v. Kline, 186 Kan. 393, 401, 350 P.2d 1093, 1104, rehearing denied, 187 Kan. 186, 354 P.2d $670(1960)$; Schloendorff v. Society of N.Y. Hosp., 211 N.Y. 127, 129, 105 N.E. 92, 93 (1914); Wilkinson v. Vesey, 110 R.I. 606, 628, 295 A.2d 676, 688 (1972).

71. See 2 F. HARPER \& F. JAMEs, supra note 39 , at 61 .

72. See Application of the President \& Directors of Georgetown College, Inc., 118 U.S. App. D.C. 80, 331 F.2d 1000, rehearing denied, 118 U.S. App. D.C. 90, 95-98, 331 F.2d 1010, 1015-18 (Burger, J., dissenting), cert. denied, 377 U.S. 978 (1964). Chief Justice Burger, then a circuit judge, felt that a hospital's effort to compel a person against her will to accept a blood transfusion was not justiciable: "Some matters of essentially private concern and others of enormous public concern, are beyond the reach of judges." 118 U.S. App. D.C. at 98, 331 F.2d at 1018. Burger alludes to notions of privacy in his discussion of the allocation of decisionmaking power. He notes that Justice Brandeis, in speaking of the "right to be let alone" . . intended to include a great many foolish, unreasonable and even absurd ideas which do not conform, such as refusing medical treatment even at great risk." $C f$. Wilkinson v. Vesey, 110 R.I. 606, 624, 295 A.2d 676, 687-88 (1972).

73. Mill's structure has been challenged. "The Millsian distinction between instances of harm to others and instances of harm solely to self, relied on by the majority, would seem rarely if ever to be relevant in actuality because others are affected by virtually any action which an individual takes or fails to take." Winters v. Miller, 446 F.2d 65, 73-74 (2d Cir. 1971) (Moore, J., concurring and dissenting), cert. denied, 404 U.S. 985 (1971). See also Devlin, Mill on Liberty in Morals, 32 U. CHr. L. REv. 215 (1965).

One problem with Mill's distinction between direct and indirect effects is that individuals are affected by psychological phenomena as well as physical or material phe- 
the decisionmaker. ${ }^{74}$ Alternatively, courts may come increasingly to view informed consent as a manifestation of constitutionally protected privacy, especially after Roe $v$. Wade. ${ }^{75}$ However, courts have explored

nomena. The distinction might be salvaged by viewing emotional impact as an indirect effect. In addition, it is arguable that purely psychological effects may be more easily (cheaply) borne by the psychologically affected party, as compared to the psychological effect of denying to an individual the right to make a decision physically affecting only himself; cf. YWCA v. Kugler, 342 F. Supp. 1048, 1073 (D.N.J. 1972) (court holds a New Jersey abortion statute unconstitutional and suggests that no authority has been advanced for the contention that for purposes of general welfare a state may infringe constitutional rights). The importance of psychological effects will be discussed later. See pp. 1660-61 infra.

The motorcycle crash helmet cases suggest some of the difficulties in allocating decisionmaking power for choices that appear primarily to affect only given individuals. Compare American Motorcycle Ass'n v. State Police, 11 Mich. App. 351, 158 N.W.2d 72 (1968), and People v. Fries, 42 IIl. 2d 446, 250 N.E.2d 149 (1969) (holding the helmet requirement invalid), with Kingery v. Chapple, 504 P.2d 831 (Alas. 1972), and State ex rel. Colvin v. Lombardi, 104 R.I. 28, 241 A.2d 625 (1968), aff'd, State v. Lombardi, 110 R.I. 776, 298 A.2d 141 (1972) (finding the requirement valid). See generally L. Tribe, Channeling Technology Through Law 367-437 (1973).

74. See J. MiLl, ON Liberty 6 (People's ed. 1873) ("the sole end for which mankind are warranted, individually or collectively, in interfering with the liberty of action of any of their number, is self-protection"). The court in American Motorcycle Ass'n v. State Police, 11 Mich. App. 351, 353, 158 N.W.2d 72, 73-74 (1968), quotes Mill as holding "that the individual is not accountable to society for his actions, insofar as these concern the interests of no person but himself." Mill also wrote, "Each is the proper guardian of his own health, whether bodily or mental and spiritual. Mankind are greater gainers by suffering each other to live as seems good to themselves, than by compelling each to live as seems good to the rest." J. Mill, supra, at 8.

The Supreme Court has expressly disavowed application of Mill's views on self-de. termination to the issue of obscenity. Paris Adult Theatre I v. Slaton, 413 U.S. 49, 68-69 \& 68 n.14 (1973) (Constitution does not preclude the regulation of allegedly obscene material exhibited in a theatre: "conduct involving consenting adults only is [not] always beyond state regulation"). With respect to libertarian political views, see also W. Godwin, Enquiry Concerning Political Justice 97-100 (K. Carter ed. 1971).

75. 410 U.S. 113 (1973). In Roe, the Court held that a Fourteenth Amendment right of privacy required the state to demonstrate a compelling interest to regulate a woman's abortion. However, the Court did not enunciate a broad right to do with one's body as one pleases. For commentary on Roe, see Ely, The Wages of Crying Wolf: $A$ Com. ment on Roe v. Wade, 82 YALE L.J. 920, 926 (1973) (problems of proper adjudication); Tribe, The Supreme Court, 1972 Term-Foreword: Toward a Model of Roles in the Due Process of Life and Law, 87 HARv. L. REv. I (1973) (decisionmaking power must be reserved to the individual where the state will interfere with religious preferences if it exercises authority). See also Eisenstadt v. Baird, 405 U.S. 438, 459.54 (1972) (distribution of contraceptives to unmarried individuals cannot be prohibited); Griswold v. Connecticut, 381 U.S. 479, 484-85 (1965) (use of contraceptives in marriage protected by right of privacy); Stanley v. Georgia, 394 U.S. 557, 564 (1969) (one may read what one wishes in the privacy of one's home); Hearings on Quality of Health Care-Human Experimentation, 1973, Before the Subcomm. on Health of the Senate Comm. on Labor and Public Welfarc, 93d Cong., 1st Sess. 1026-32 (1973).

A Pennsylvania lower court recognized the connection between privacy and the right to refuse. In a case involving the refusal of a chronic undifferentiated schizophrenic to submit to cancer therapy, the court upheld her freedom to refuse declaring:

In our opinion the constitutional right of privacy [citing Roe v. Wade, 410 U.S. $113(1973)]$ includes the right of a mature competent adult to refuse to accept medical recommendations that may prolong one's life and which, to a third person at least, appear to be in his best interests; in short, that the right of privacy includes a right to die with which the State should not interfere where there are no minor or unborn children and no clear and present danger to public health, welfare or morals. If the person was competent while being presented with the decision and in making the decision which she did, the Court should not interfere even though her decision might be considered unwise, foolish or ridiculous. 
the connection between informed consent and constitutional doctrine most in the context of freedom of religion. ${ }^{76}$ Competent, informed patients have been held entitled to refuse treatment solely because of religious beliefs, even if the treatment is necessary to preserve their lives. ${ }^{77}$ Constitutional rights may thus indeed lie at the foundation of informed consent doctrine, but the issue remains far from settled. ${ }^{78}$

The doctrine's underpinnings, however, may also be explained in terms more commonly applied to tort doctrine in general. To the extent that tort law seeks to achieve an efficient allocation of resources, it aspires to place the responsibility for particular decisions upon the

In re Yetter, Civil No. 1973-533, at 4 (Pa. C.P. Northampton Co., June 6, 1973) (copy on file with the Yale Law Journal). See also Merriken v. Cressman, 364 F. Supp. 913 (E.D. Pa. 1973) (personality test used by a school to identify potential drug abusers without informed consent of the parents held to violate the student's and parents' right of privacy), noted in 27 VAND. L. REv. 372 (1974). For an early exposition of the right to privacy, see Warren \& Brandeis, The Right of Privacy, 4 Harv. L. Rev. 193 (1891).

76. See Winters v. Miller, 446 F.2d 65 (2d Cir. 1971), rev'g 306 F. Supp. 1158 (E.D.N.Y. 1969), cert. denied, 404 U.S. 985 (1971) (Christian Scientist); Montgomery v. Board of Retirement, 33 Cal. App. 3d 447, 109 Cal. Rptr. 181 (1973) (denial of retirement benefits to employee whose religious beliefs prohibited life-saving surgery, rendering her disabled, unconstitutionally infringed employee's free exercise of religion); In re Osborne, 294 A.2d 372 (D.C. App. 1972) (Jehovah's Witness); Marcus, The Forum of Conscience: Applying Standards Under the Free Exercise Clause, 1973 DukE L.J. 1217, 1251-54. It has also been argued that the First Amendment gives rise to a right of "mentation" (cognition, understanding, perception and emotion) and that informed consent doctrine protects a right of mentation against "coercive intrusion." Shapiro, Legislating the Control of Behavior Control: Autonomy and the Coercive Use of Organic Therapies, 47 S. CAL. L. REv. 237, 253-76, 307 (1974).

77. See In re Osborne, 294 A.2d 372 (D.C. App. 1972), distinguishing John F. Kennedy Memorial Hosp. v. Heston, 58 N.J. 576, 279 A.2d 670 (1971) (ordering life-saving blood transfusion) as protecting the lives of unborn children. 294 A.2d at 374 n.3. This is a strained interpretation of Heston; perhaps the court should have argued that Heston was wrongly decided. In any event, to the extent that Osborne correctly characterized Heston as protecting the lives of unborn children, Heston has perhaps been partially overruled by Roe v. Wade, 410 U.S. 113 (1973) (legalizing certain abortions as within the zone of constitutionally protected privacy). Further, if Roe weakens Heston, it certainly weakens cases like Raleigh Fitkin-Paul Morgan Memorial Hosp. v. Anderson, 42 N.J. 421, 423, 201 A.2d 537, 538, cert. denied, 377 U.S. 985 (1964) (held that a woman may be compelled to accept blood transfusions because her unborn child is entitled to the law's protection).

A patient's custody of a minor child does not necessarily compel overruling his or her refusal of treatment. Osborne upheld the patient's mature decision to forego a transfusion against state intervention; the two minor children could be cared for by rest of family and the family business would continue to provide support. 294 A.2d at 374. In at least two reported cases, Winters v. Miller, 446 F.2d 65 (2d Cir.), cert. denied, 404 U.S. 985 (1971) (patient involuntarily committed to a hospital for treatment of an alleged mental illness and compelled over her objections to take tranquilizers), and Holmes v. Silver Cross Hosp., 340 F. Supp. 125 (N.D. Ill. 1972), patients who were forced by health care providers in league with lower state courts to submit to treatment over religious objections were held to have stated causes of action under the Civil Rights Act of 1871,42 U.S.C. $\$ 1983$ (1970). On damages under 42 U.S.C. $\$ 1983$, see Note, Monetary Claims Under Section 1983: The Right to Trial By Jury, 8 Harv. Civ. Rights-Civ. LiB. L. Rev. 613, 620-22, 625-26 (1973).

78. This issue has received considerable attention in the secondary literature. See, e.g., Cantor, supra note 5; Survey, supra note 16; Note, Is There a Right to a Natural
Death?, 9 NEw ENG. L. REv. 293, 308-09 (1973). 
individuals who can best avoid costs arising from that decisionmaking. ${ }^{79}$ This cost avoidance includes an effort to reduce the number and severity of incorrect decisions, and an attempt to reduce the costs of gathering and considering information in making decisions. ${ }^{80}$ Decisionmaking for purposes of informed consent may be evaluated in terms of cost avoidance. The physician is primarily an expert in diagnosis and treatment who can determine at less expense than the patient the desirability of a particular treatment from a medical point of view. However, the physician is not equipped to evaluate a treatment in terms of a patient's nonmedical needs. The cost to the physician of discovering all the patient's psychological, social, and business needs and obligations is simply too great. Only the patient knows sufficiently his own value preferences, capacity for pain and suffering, future business and social plans, and religious beliefs to evaluate the desirability of a particular treatment so it will maximize the patient's satisfaction. Moreover, a system which overtly ignored the individual values of patients might encourage them to avoid or delay consulting physicians for fear that their values would be disregarded. ${ }^{81}$ This would risk deterioration of health standards at considerable cost to society as individuals neglected to seek medical advice.

This analysis suggests that the most efficient decisionmaking method for medical treatment places responsibility on the physician to make sufficient medical disclosures to his patients. On the basis of both the medical information and his own values, the patient would then be responsible for evaluating alternative procedures proposed by the physician and for making the ultimate decision as to the most appropriate treatment. The physician would be liable for insufficient disclosure, but the patient would bear the risks of the treatment or nontreatment which he selected after receiving adequate information. As the previous discussion indicated, recent informed consent cases have

79. See generally G. CAlabresi, The Costs of Accidents (1969). Tort law, of course, also seeks goals other than efficient allocation of resources.

80. Cf. id. at 26-28.

81. Cf. Lacy v. Harris Co. Welf. Unit, Civil No. 74-H-124 (S.D. Tex,, filed Jan. 22,1974 ). In Lacy, a $\$ 1983$ case, a blood transfusion was recommended for an infant in Florida. The parents, Jehovah's Witnesses, had the child flown to a Texas hospital which treated such patients without transfusions. The plaintiffs alleged that the Florida physician told a hospital and welfare unit in Texas that the infant was in immediate danger of death. The welfare unit secured a court order, without notice, making the child a ward of the state. The sheriff then transferred the Lacy infant to a general hospital where he received blood transfusions. Complaint of plaintiffs, id.; Letter from Patrick J. Leston to Charles H. Montange, Apr. 9, 1974 (copy on file at Yale Law Journal). 
moved in this direction of an economically efficient allocation of decisionmaking authority. ${ }^{82}$

\section{Implications for Euthanasia}

Society engages in a denial of death. ${ }^{83}$ This denial of death entails two attitudes which must be squarely confronted and overcome in order to achieve reasoned discussion of voluntary euthanasia. First, the denial has encouraged the view that society attaches unqualified paramount value to human life, or, put another way, that society engages in thoroughgoing protection of life. In actuality such protection is an illusion, for society has tended to prevent only direct takings of life, while permitting the indirect, but statistically certain, deaths. ${ }^{84}$ For example, the recent reduction of speed limits on highways during the energy shortage made clear that the higher speeds tolerated for years have resulted in a substantially higher death toll. ${ }^{85}$ Death of a human being should be of equal concern whether direct or indirect. Direct takings, however, would confront the denial by shattering the illusion, whereas the illusion may be maintained when the takings are indirect. Voluntary euthanasia is sufficiently open and direct ${ }^{86}$ that it constitutes an explicit challenge to the illusion.

Second, denial of death has made many unable to appreciate that a dying person may accept the prospect of death "with equanimity

82. This analysis applies to other than doctor-patient relations. See Fleming v. Delta Airlines, 359 F. Supp. 339 (S.D.N.Y. 1973) (airline owes duty to warn passengerin this case a doctor-of expected turbulence so that he might choose for himself whether he is "physically and emotionally capable of undertaking the trip" and wishes to do so), noted in 42 Fordham L. Rev. 698 (1974); Smith v. Lewis, 107 Cal. Rptr. 95, 101 (attorney should disclose information relevant to divorce settlement), deleted from reporter due to hearing granted, 31 Cal. App. 3d 677 (1973); Freese v. Lemmon, 210 N.IW.2d 576 (Iowa 1973) (physician may be liable for injury to third party caused by the automobile of patient who experienced seizure, where doctor failed to warn patient of possibility of seizures). In each case the defendant may be seen as the optimal cost avoider.

83. See, e.g., A. ToYNBE, Changing Attitudes Toward Dealh in the Modern World, in Man's Concern with DeATH 129 (1968); Kübler-Ross, Life and Death: Lessons from the Dying, in To Live AND To DIE, supra note 5, at 150-59; Wahl, The Physician's Treatment of the Dying Patient, I64 ANNals N.Y. ACAD. ScI. 759 (1969); Hearings on Dying, supra note 5, at 4, 12-13, 114-17.

84. Calabresi, Reflections on Medical Experimentation in Humans, 98 DAEDALus 387 (1969). Calabresi points out that society seems quite willing to trade lives in order to achieve cheaper social progress. For example, society knows statistically that deaths will result from unsafe mines, automobiles, and airports but nevertheless refuses to spend the money to save the lives. Ely adverts to the anomaly of society's preference for "indirect" as opposed to "direct" taking of life as "the psychological phenomenon that keeps bombardiers sane-the fact that it is somehow easier to 'terminate' those you cannot see . . . Ely, supra note 75, at 927. Adverse psychological effects of direct taking of life do, however, affect people's utility curves. See pp. 1660-61 infra.

85. See N.Y. Times, Feb. 3, 1974, at 30, col. 4; id., Nov. 27, 1973, at 31, col. 4.

86. Cf. Cantor, supra note 5, at 243-45. 
and without mental disturbance." 87 This in turn prompts the attitude that a decision to die by a terminal patient is a manifestation of mental incompetency; hence that a terminal patient cannot competently consent to any form of euthanasia. ${ }^{88}$

Once one begins to see through these attitudes, the question becomes not, "Why make an exception permitting a death?" but rather, "What exceptions should be made?"s9 This latter question may be addressed in part through the doctrine of informed consent.

The patient's right to an informed consent makes no sense without a right to an informed refusal. The right to refuse should be extended to the dying patient, for his decision on proffered treatment is no different from that involved in any other medical situation. ${ }^{00}$ The individual continues to know best his own value preferences, capacity for pain and suffering, and uncompleted business and social obligations. He remains the optimal cost avoider.

The problem of euthanasia can be viewed as a continuum of situations requiring implementation of the patient's right to be the decisionmaker. At one end of the continuum is the nonterminal patient confronted with risks and alternatives in selecting treatment. Next is the terminal patient deciding whether to submit to life-sustaining therapy. Further along the continuum comes the terminal patient

87. E. Kübler-Ross, supra note 2, at 112-37; A. Weisman, ON Dying and Denyang 30-31 (1972). But cf. Feifel, Perception of Death, 164 Annals N.Y. ACad. ScI. 669 (1969).

88. Another explanation for attitudes toward voluntary euthanasia is that physicians psychologically are oriented more toward prolonging life or "winning." Hearings on Dying, supra note 5 , at $46-51$.

89. Cf. Calabresi, supra note 84 .

90. See Erickson v. Dilgard, 44 Misc. 2d 27, 252 N.Y.S.2d 705 (Sup. Ct. 1962). See also In re Yetter, Civil No. $1973-533$ (Pa. C.P. Northampton Co., June 6, 1973) (copy on file with the Yale Law Journal); Sullivan, The Dying Person-His Plight and His Right, 8 NEw ENG. L. REv. 197 (1973) (describes two cases involving refusal); 2 F. HARPER \& F. JAMEs, supra note 39 , at 61 :

The very foundation of the doctrine [of informed consent] is every man's right to forego treatment or even cure if it entails what for him are intolerable consequences or risks, however warped or perverted his sense of values may be in the eyes of the medical profession, or even of the community, so long as any distortion falls short of what the law regards as incompetency. Individual freedom here is guaranteed only if people are given the right to make choices which would generally be regarded as foolish ones. Thus the Jehovah's witness should have the legal right to refuse-on religious grounds which seem mistaken to most of usthe blood transfusion which is needed to save his life ....

Cantor, supra note 5, at 261-62, points out, however, that approval of active euthanasia is not compelled by the notion of a right of refusal.

The right to refuse treatment was recognized in controversial Provision Four in the American Hospital Association version of the "Patient's Bill of Rights." This provision was not included in the Patient's Bill of Rights as enacted in Minnesota. MinN. Stat. AnN. \$ 688 (Supp. VI, 1973). See also H. Denenberg, Citizens Bill of Hospital Righrs 6 (1973); Annas \& Healey, The Patient Rights Advocate: Redefining the DoctorPatient Relationship in the Hospital Context, 27 VAND. L. REv. 243, 255.57, 265-68 (1974); Curran, The Patient's Bill of Rights Becomes Law, 290 New ENG. J. MED. 32-33 (1974). 
requesting the discontinuance of a life-sustaining treatment. Finally there is the terminal patient requesting that his life be shortened by rendition of a death-inducing agent.

The doctrine of informed consent requires that the competent, nonterminal patient in a nonemergency situation be given a chance to consent or refuse. ${ }^{91}$ The situation is no different for the terminal patient advised by his doctor to undergo a particular treatment. $\mathrm{He}$ should likewise have a choice, since the decision involved is analytically the same as in the first case. ${ }^{22}$

However, the case of the competent terminal patient requesting discontinuance of life-sustaining treatment presents several problems. Arguably, once a patient submits to a life-sustaining treatment, the physician has an obligation not only to him but also to society to maintain him, as a minimum, in his present condition. ${ }^{93}$ In addition, a patient is sometimes viewed as submitting to the physician's "professional standards" or "school of practice" when he requests treatment. ${ }^{24}$ According to this view, the physician may thereafter treat the patient according to his school, which may mean that termination of treatment before death will not be permitted.

This argument forces the patient to choose between extreme alternatives. The patient is compelled either to forego treatment altogether or, once treatment commences, to submit completely to the physician's decisions. This failure to honor the patient's decision to terminate treatment converts the initial consent into a contract of adhesion from which the patient is permitted no escape even though new facts might be brought to his attention after his initial consent.

The primary duty of the physician should not be only to act in the best interests of the patient as defined by some school of practice, but rather to act in the best interests of the patient as the patient himself views those best interests. Self-determination, the basis of informed

91. Cf. 2 F. Harper \& F. JAMEs, supra note 39, at 61; Canterbury v. Spence, 150 U.S. App. D.C. 263, 271-74, 281-82, 464 F.2d 772, 780-83, 790-91, cert. denied, 409 U.S. 1064 (1972). 92. See Erickson v. Dilgard, 44 Misc. 2d 27, 252 N.Y.S.2d 705 (Sup. Ct. 1962). See also Sullivan, supra note 90, at 197 (cases discussed); In re Yetter, Civil No. 1973-533 (Pa. C.P. Northampton Co., June 6, 1973) (copy on file with the Yale Law Journal).

93. See Kamisar, Some Non-Religious Views Against Proposed "Mercy-Killing" Legislation, 42 MinN. L. REv. 969, 1042 (1958).

94. See John F. Kennedy Memorial Hosp. v. Heston, 58 N.J. 576, 583, 279 A.2d 670, 673 (1971); cf. Application of President \& Directors of Georgetown College, Inc., 118 U.S. App, D.C. 80, 89, 331 F.2d 1000, 1009, rehearing denied, 118 U.S. App. D.C. 90, 331 F.2d 1010, cert. denied, 377 U.S. 978 (1964). See also Hearings on Dying, supra note 5, at 81-83. "Professional standards" or "school of practice" refers to the basic theory of medicine under which the health care provider is trained. To that extent, the notion distinguishes medical doctors, osteopaths, and chiropractors. See D. HARNEY, Medical Malpractice 101-07 (1973); Perdue, The Law of Texas Medical Malpractice, II Hous. L. REV. 1, 29-32 (1973). 
consent, implies that a competent patient must have the right to redefine his best interests for the duration of a medical procedure. Hence, the patient should be able to withdraw his consent at any time and discontinue the treatment.

This passive euthanasia presents fewer difficulties than the final case of active rendition of a death-inducing agent once a competent terminal patient so requests. In that situation, another person is involved who assists in ending the patient's life. Such assistance renders the person liable to prosecution for homicide. Nor can this conclusion be escaped by analyzing the other's act as merely an extension of the patient's will ${ }^{95}$ since consent is not usually a defense to homicide..$^{96}$

Nevertheless, the difficulty of distinction between active and passive euthanasia should be recognized. Because these cases are on a continuum, there may be little or no substantive difference between termination of treatment and active rendition of a death-provoking agent. ${ }^{97}$ Termination of treatment may involve turning off a respirator switch whereas active rendition may involve giving an injection. A physical act by a third person which promotes a less prolonged dying process is involved in each instance. Termination, however, may seem less direct than active rendition and therefore more acceptable. On the other hand, active rendition maximizes the self-determination of the terminal patient by allowing the maximal choice over the timing of death. The alternatives in the terminal situation are not living or dying; they are either a prolonged death or a quicker death that main. tains what the patient regards as his dignity. Granting choice over timing of death to a terminal patient need not conflict with concern for preservation of life. Preservation of life becomes grotesque when forced on a competent terminal patient who prefers a more rapid end. Concepts of sanctity of life should be recognized as not absolute; 88 they do not inevitably imply that society should deny the decision of a terminal patient electing euthanasia, either active or passive..$^{90}$

95. See, e.g., Note, supra note 16, at 694 .

96. See S. Kadish \&: M. Paulsen, Criminal Law and Its Processes 15 (2d ed. 1969) (consent is no defense except in some sports contests).

97. Cf. G. WILliams, SANCTITY of LIFE 319 (1958). For an attempt to distinguish, see Hearings on Dying, supra note 5, at 20-21.

98. See Reeves, When Is It Time to Die? Prolegomenon to Voluntary Euthanasia, 8 NEW ENG. L. REv. 183, 194 (1973).

99. Two recent proposals for the rendition of euthanasia neglect the implications of informed consent. Glanville Williams, recognizing the precarious legal position of health care providers in deciding on proper treatment of terminal patients, has called for legislation leaving euthanasia to the physician's discretion. Williams, Euthanasia, 41 Medico-Legal $J$. 14, 16 (1973). Williams favors a statute legalizing euthanasia in order to minimize the risk of lawsuits. The second proposal is to analyze the discontinuance of treatment as an omission, rather than as an act, thus producing no criminal liability. 


\section{Closing Competency Loopholes}

Even in those jurisdictions which have eliminated the medical community standard as the test for adequacy of disclosure, physicians may still escape liability for failure to disclose material information. This is true for two reasons. First, the patient may be deemed incompetent, in which case information need be provided not to the patient but only to the family. ${ }^{100}$ Second, the physician might feel the patient would be "upset" by the information and therefore withhold the relevant facts on grounds of therapeutic privilege. ${ }^{101}$

These grounds for failing to provide information may be abused, creating a loophole through which the implications of informed consent may be avoided. Because of his lack of expertise in comparison to the physician, the patient must rely heavily upon the doctor for information concerning the quality and nature of the treatment. ${ }^{102}$ It has been suggested that physicians in fact attempt to manipulate or

However, turning off a respirator and failing to turn on a respirator which is automatically programmed to stop every 24 hours, are not morally different; distinguishing the former as an act seems artificial. See id. at 21. See also Fletcher, Prolonging Life, 42 Wash. L. Rev. 999, 1007 (1967); Kamisar, supra note 93, at 982 n.41. Because the distinction between acts and omissions is vague, an effort has been made to lend substance to the "act" versus "omission" dichotomy by looking to standard medical practice in a community to determine whether the doctor's behavior constitutes an act or omission. See Fletcher, supra; cf. Gurney, supra note 5, at 243-44. The argument is that if doctors do not generally treat a dying patient under certain circumstances, then failure to treat is an omission and no liability arises.

Neither doctor nor profession should have legal discretion to determine whether cuthanasia will be rendered; cf. Hearings on Dying, supra note 5 , at 75 . If a decision to die is to be made, it should be made by the patient himself if competent, and not by the patient's physician or by a medical community standard. Further, there is evidence that doctors are neither trained nor better able to make the decision. See B. Bird, TAlking with PAtients 77 (2d ed. 1973); E. Kübler-Ross, supra note 2, at 11-12, 18.21; Hearings on Dying, supra note 5, at 51. See also Kamisar, supra note 93, at 992.93, 996. Medical literature is beginning to examine the problem of such decisionmaking. See Duff \& Campbell, Moral and Ethical Dilemmas in the Special-Care Nursery, 289 NEw ENG. J. MED. 890 (1973) (investigation of deliberate infant deaths); Shaw, Dilemmas of "Informed Consent" in Children, 289 NEw ENG. J. MED. 885 (1973) (treatment of critically ill children). See generally Smith, On Letting Some Babies Die, HASTINGS CENTER Studies, May 1974, at 37 (discusses Shaw and Duff \& Campbell articles); Letters to the Editor, 290 NEw ENG. J. MED. 518, 864 (1974).

Another line of thought suggests that motive, as opposed to intent, be reintroduced into the criminal law. See, e.g., Kutner, supra note 5, at 549; Note, supra note 16, at 675. According to this view, good faith rendition of euthanasia derives from a good motive, and should therefore not be punished, or should be punished as a lesser offense than murder; of. Parry-Jones, Criminal Law and Complicity in Suicide and Attempted Suicide, 13 MED., ScI. \& L. 110 (1973).

100. See, e.g., Cobbs v. Grant, 8 Cal. 3d 229, 244, 502 P.2d 1, 10, 104 Cal. Rptr. 505, 514 (1972).

101. See, e.g., Wilkinson v. Vesey, 110 R.I. 606, 628, 295 A.2d 676, 689 (1972).

102. See Canterbury v. Spence, 150 U.S. App. D.C. 263, 273, 464 F.2d 772, 782, cert. denied, 409 U.S. 1064 (1972). In economic terms, this reliance is the product of the high cost to the patient of informing himself of the relevant medical information other than through his physicians. He cannot readily determine for himself the quality of the care which he is receiving, and must rely on self-regulation by physicians, or on standards set by law to assure that quality medical services are provided. 
enhance patient uncertainty in order to preserve power over the patient in the doctor-patient relationship. ${ }^{103}$ Such control over the patient, being contrary to interests in self-determination sought to be protected by informed consent, must be restrained. Consequently, the courts should be particularly alert to prevent manipulation of the patient. This concern may be expressed by the formulation of adequate legal safeguards to control determinations of competency and the use of therapeutic privilege.

Unfortunately, some courts tend to confuse competency to consent with competency to receive certain "upsetting" information. ${ }^{104}$ Further, even when the concepts are kept separate, adequate legal tests protective of patient interests have not been forthcoming. This Note will examine separately the two notions, and offer approaches designed to maintain and safeguard patient self-determination.

\section{A. Competency to Consent}

Courts generally except from the requirement of informed consent persons who are not competent. ${ }^{105}$ Information need not be tendered nor consent obtained from an incompetent patient, though an informed consent must be obtained from the patient's guardian. ${ }^{100}$ The definition of competency is critical. It must be formulated consistently with the objective of informed consent-to secure for the patient the right to forego treatment even if the medical profession or society

103. See Waitzkin \& Stoeckle, The Communication of Information about Illness, 8 Adv. Psychosom. Med. 180, 185-89 (1972). This is not to suggest that all physicians manipulate uncertainty, nor that the medical profession has a monopoly on such manipulation.

104. Cobbs v. Grant, 8 Cal. 3d 229, 502 P.2d 1, 104 Cal. Rptr. 505 (1972), presents a test for competency which may reflect confusion with physicians' claims of therapeutic privilege to withhold upsetting information from the patient:

A disclosure need not be made beyond that required within the medical community when a doctor can prove by a preponderance of the evidence [that] he relied upon facts which would demonstrate to a reasonable man the disclosure would have so seriously upset the patient that the patient would not have been able to dispassionately weigh the risks of refusing to undergo the recommended treatment.

Id. at 246, 502 P.2d at 12, 104 Cal. Rptr. at 516.

The requirement of dispassionate evaluation of risks undermines the doctrine of informed consent which requires that a patient be permitted to refuse treatment even for reasons others regard as irrational or hastily conceived. Further, cobbs does not explain why medical community standards exist for disclosure to incompetent patients. Elsewhere in the opinion the court strongly criticized the notion of medical community standards, calling them "nebulous" and charging that they vest doctors "with virtual absolute discretion." Id. at 243, 502 P.2d at 10, 104 Cal. Rptr. at 514.

105. See, e.g., id. at 244, 502 P.2d at 10, 104 Cal. Rptr. at 514. The Schloendorff principle as stated by Judge Cardozo presupposes that the person is of "sound mind." Schloendorff v. Society of N.Y. Hosp., 211 N.Y. 125, 129, 105 N.E. 92, 93 (1914).

106. See, e.g., Bonner v. Moran, 75 U.S. App. D.C. 156, 157-58, 126 F.2d 121, 122-23 (1941). 
would feel the reasons to be irrational. ${ }^{107}$ At the outset, it should be noted that competency may be defined in different ways for different purposes. ${ }^{108}$ Therefore, the discussion following will elaborate a concept of competency applicable specifically for informed consent to medical treatment.

Judicial opinions dealing with informed consent generally do not articulate tests for competency. Apparently courts are usually content to rely on physicians' unguided judgments as to what constitutes competency to consent. However, some courts have been successful in establishing a legal test for competency which both serves the interests of informed consent and avoids confusion with therapeutic privilege.

The Supreme Court of Washington set forth such a test of competency in Grannum v. Berard. ${ }^{109}$ Competency is presumed; to overcome this presumption, clear, cogent, and convincing evidence is necessary. The test of competency is the same as that used to determine the capacity of an individual to execute an agreement. ${ }^{110}$ Thus, the question is whether the person at the time of making the agreement possessed sufficient reason to understand the nature, terms, and effect of the agreement. ${ }^{111}$ This test focuses on the patient's capacity to comprehend his situation, risks, and alternatives. It does not import an examination of whether the patient's choice is rational or dispassionately conceived, but allows a patient to make decisions which may seem to others to be unreasonable. ${ }^{112}$

\section{B. Therapeutic Privilege: The Patient's Competency to Receive Certain Information}

Many courts have permitted doctors to exercise a therapeutic privilege to withhold information which they believe might seriously upset or depress patients. ${ }^{113}$ Concealment is thus permitted even from an

107. See p. 1653 infra.

108. See Sieling v. Eyman, 478 F.2d 211, 214 (9th Cir. 1973) (competency to plead guilty is different from competency to stand trial).

109. 70 Wash. 2d 304, 422 P.2d 812 (1967).

110. See id. at 307,422 P.2d at 814 .

111. Peterson v. Eritsland, 69 Wash. 2d 588, 594, 419 P.2d 332, 336 (1966); Woods v. Dunlop, 510 P.2d 260, 264 (Wash. App. 1973). See also Smith v. Seibly, 72 Wash. 2d 16, 22, 431 P.2d 719, 723 (1967).

112. See In re Yetter, Civil No. 1973-533, at 5 (Pa. C.P. Northampton Co., June 6, 1973) (copy on file with the Yale Law Journal); cf. Woods v. Dunlop, 510 P.2d 260, 265 n.4 (Wash. App. 1973): "If a person possesses the mental capacity to contract, and voluntarily executes a release in exchange for something of value, the mere fact that such party makes an improvident or bad bargain, in and of itself, is not a sufficient basis to avoid the effect of the release ...."But cf. Demers v. Gerety, 515 P.2d 645, 654 (N.M. Ct. App. 1973) (concurring opinion).

113. See Karp v. Cooley, 349 F. Supp. 827, 834-35 (S.D. Tex. 1972); Natanson v. Kline, 186 Kan. 393, 406, 350 P.2d 1093, 1103, rehearing denied, 187 Kan. 186, 354 P.2d 
apparently competent patient. In Nishi v. Hartwell, ${ }^{114}$ a recent Hawaiian case, information was concealed from a competent patient on grounds of therapeutic privilege, and was also concealed from the patient's wife. The court held that no disclosure to the family was necessary, since the patient was competent, even when information was concealed from the patient to avoid "upsetting" him. ${ }^{115}$

This decision fails to consider the interest of the patient and his family in receiving information so they might prepare for contingencies. Furthermore, it fails to provide protection against manipulating the consent of the patient by selective provision of information. Finally, although the Hawaii court avoided this analysis, the invocation of therapeutic privilege implies a judgment that the patient is incompetent to receive certain material information which might be distressing. It is contradictory at the same time to view him as competent to consent. Meaningful consent requires disclosure of material information. If a patient is not competent to receive all material information, then he is not competent to give a valid consent. In such a case consent should be sought from an informed family or guardian.

Canterbury v. Spence ${ }^{116}$ recognized that the "physician's privilege to withhold information for therapeutic reasons must be carefully circumscribed ... for otherwise it might devour the disclosure rule itself." 117 Canterbury unfortunately places only an outer limit on the privilege, ${ }^{118}$ but it does suggest that disclosure to a close relative is necessary if the privilege is exercised. The opinion represents a move-

670 (1960) (possible privilege to withhold information if disclosure seriously jeopardizes the recovery of unstable patient); Aiken v. Clary, 396 S.W.2d 668, 674 (Mo. 1965); Watson v. Clutts, 262 N.C. 153, 159, 136 S.E.2d 617, 621 (1964) ("Any conflict between [the doctor's primary duty to do what is best for the patient] and that of a frightening disclosure ordinarily should be resolved in favor of the primary duty"); ZeBarth v. Swedish Hosp. Med. Center, 81 Wash. 2d 12, 25-26, 499 P.2d 1, 9-10 (1972); Waltz \&: Scheuneman, supra note 8 , at $641-42$.

114. 52 Hawaii 188, 473 P.2d 116 (1970). In this case, a "well-educated" dentist was not told about the hazards of injection of radio-opaque contrast medium as he was "frightened," had hypertension, and had heart disease, even though he was "mentally competent and had the capacity to act." The dentist was paralyzed from the waist down with loss of control of his bowel and bladder, a known risk of the contrast medium. Id. at 190-93, 199, 473 P.2d at $118-20,123$.

115. Id. at $198-99,473$ P.2d at $122-23$.

116. 150 U.S. App. D.C. 263, 464 F.2d 772, cert. denied, 409 U.S. 1064 (1972).

117. Id. at 280,464 F.2d at 789 . This recognition is not surprising since claims of therapeutic privilege to conceal information achieve the same results as assertions of a community standard against disclosure. Since Canterbury rejected the community standard rule, the court quite properly applied the same logic to cut back therapeutic privilege.

118. Id. The court forbade "paternalistic" use of the privilege to engineer a competent patient's consent to an operation by withholding information which might prompt the patient to forego the treatment. 
ment toward viewing invocation of therapeutic privilege as equivalent to an assertion that the patient is incompetent.

Doctors would be caught between Scylla and Charybdis ${ }^{119}$ if they are restricted in the use of therapeutic privilege but yet are held liable for making frightening disclosures to competent patients. Unfortunately there are indications in some jurisdictions that physicians will be held liable in damages for mental anguish caused by disclosures. ${ }^{120}$ Any tendency of the law in the direction of holding doctors liable for any honest disclosures must be closely scrutinized, for it may impede the flow of material information to the patient.

In place of permissive judicial approaches allowing therapeutic privilege and of intimations that physicians may be liable for frightening disclosures, the law should concentrate on developing a duty to inform patients carefully of material information, even if it is distressing. ${ }^{121}$ Requiring a tactful disclosure would provide the patient with the information necessary to make an informed decision while avoiding excessive discomfort in the patient. ${ }^{122}$ The interest in selfdetermination of a competent patient is not served by distorted infor-

119. See Homer, The Odyssey 212 (Anchor ed. 1963) (translates the dreadful couple as Skylla and Kharybdis).

120. In the New Zealand case of Furniss v. Fitchett, 1958 N.Z.L.R. 396, 404, a doctor informed a husband of his wife's mental condition; he then sprang the news on her in a divorce proceeding. The court stated that "in the circumstances ...., the doctor owed to his patient at common law a duty to take reasonable care to ensure that no expression of his opinion as to her mental condition should come to her knowledge." The case elicited the suggestion that it meant that a doctor owed a duty to be tactful in his explanation. Inglis, Furniss v. Fitchett: $A$ Footnote, 34 N.Z.L.J. 235, 236 (1958). An American case similar on its facts to Furniss is Schaffer v. Spicer, 215 N.W.2d 134 (S.D. 1974) (physician's disclosure of mental problems of ex-wife to ex-husband's attorney in child custody contest is breach of physician-patient privilege). See also Horne v. Patton, 291 Ala. 701, 287 So. 2d 824 (1973). Some commentators have felt that there is no Furniss liability for disclosure in the United States since recovery for emotional harm requires some "impact." Waltz \& Scheuneman, supra note 8 , at 641 n.48. However, several cases indicate that "impact" does not represent an obstacle to recovery for distressing disclosure. See, e.g., Winik v. Jewish Hosp. of Brcoklyn, 31 N.Y.2d 936, 293 N.E.2d 95, 340 N.Y.S.2d 927 (1972), aff'g 35 App. Div. 2d 982, 317 N.Y.S.2d 1004 (1970) (no recovery where fear of cancer not reasonable nor attributable to surgeon's negligence); Trapp v. Mfetz, 28 N.Y.2d 913, 271 N.E.2d 697, 323 N.Y.S.2d 166 (1971), rev'g 35 App. Div. 2d 851, 317 N.Y.S.2d 614 (1970) (patient may recover for anxiety due to mistaken diagnosis): Ferrara v. Galluchio, 5 N.Y.2d 16, 152 N.E.2d 249, 176 N.Y.S 2d 996 (1958) (liability for starting cancerphobia); Kraus v. Spielberg, 37 Misc. 2d 519, 236 N.Y.S.2d 143 (Sup. Ct. 1962) (liability for psychic injury but only if disclosure is grossly negligent, capricious, not well founded, and induces harmful therapy). See also D'Âmbra v. United States, 354 F. Supp. 810 (D.R.I. 1973) (bystander parent may recover for mental anguish upon seeing child negligently injured, "impact" being found in the sensory observation); Tobin v. Grossman, 24 N.Y.2d 609, 249 N.E.2d 419, 301 N.Y.S.2d 554 (1969) (negligently induced mental trauma supports a cause of action but not as to third parties); $c f$. Jacobs v. Theimer, 507 S.W.2d 288 (Tex. Civ. App. 1974).

121. Cf. Inglis, supra note 120 .

122. Cf. Hearings on Dying, supra note 5, at 11 (Kübler-Ross testified that dying patients could receive information as long as they were given "hope"). 
mation. ${ }^{123}$ Furthermore, there is evidence that patients desire a full disclosure, even of distressing information. ${ }^{124}$ Courts should permit only one exception to this rule of full tactful disclosure. A physician should exercise a therapeutic privilege to withhold information from a competent patient when the patient expressly waives his right to a disclosure. ${ }^{125}$ However, in order to avoid abuse, courts should insist that the waiver be express and unequivocal, and not a doctor's inference from subjective impressions of the competent patient's behavior. ${ }^{120}$

\section{Competency and the Dying Patient}

It might be argued that a decision by a terminal patient to refuse treatment provides prima facie evidence of mental incompetency or is itself so irrational that it should be disregarded. However, given the patient's implicit choice between prolonged dying or more rapid death, a decision to die may be quite reasonable even if other individuals or groups in our society judge it unacceptable for themselves. If a terminal patient were to decide to die for what others would deem irrational reasons, the decision should still be honored; informed consent protects all decisions by competent patients, rational or irrational. ${ }^{127}$ This proposition was recognized in In re Yetter, ${ }^{128}$ a Pennsylvania lower court case which held a schizophrenic sufficiently

123. The communication of information also serves other interests, including enhancement of the accuracy of history-taking, provision of more useful medical records, augmentation of patients' compliance with therapeutic regimens, increase of patients' satisfaction, and improvement of patients' physiologic and psychologic responses to therapy. See Waitzkin \& Stoeckle, supra note 103, at 183.85.

124. See, e.g., Alfidi, Informed Consent-A Study of Patient Reaction, 216 J.A.M.A. 1325 (1971). This study of patients informed of "serious" complications of angiography concludes that "the vast majority of patients desired this information" and "a straightforward statement of complications will result in only a small percentage of patients refusing a special procedure." Id. at 1329 .

125. See, e.g., Cobbs v. Grant, 8 Cal. 3d 229, 245, 502 P.2d 1, 12, 104 Cal. Rptr. 505, 516 (1972) (allows waiver).

126. Waiver of informed consent is suspect, for the patient "may be ignorant, confused, overawed by the physician, or frightened by the hospital ..." or ashamed to take the physician's time by obtaining information. See Canterbury v. Spence, 150 U.S. App. D.C. 263, 274 n.36, 464 F.2d 772, 783 n.36, cert. denied, 409 U.S. 1064 (1972), citing Note, supra note 8 , at 1545.51 . Thus it may be argued that the importance of selfdetermination is so great that informed consent may never be waived in a nonemergency situation. However, waiver may be acceptable if courts ensure that the patient is not intimidated into waiving an informed consent by pressure from a hurried physician. If the patient clearly understands that the physician would willingly give the information and that waiver means that the physician will make the final decisions, waiver might be permitted, since the patient may determine that the emotional cost to himself of the information or of the decisionmaking is too great.

127. See note 90 supra.

128. Civil No. $1973-533$ (Pa. C.P. Northampton Co., June 6, 1973) (copy on file with the Yale Law Journal). 
competent to refuse life-saving surgery even though the patient's grounds for refusal were considered by some as irrational. ${ }^{129}$

Some commentators have argued that terminal patients may be particularly vulnerable to the influence of family members, drugs, pain, or financial factors. ${ }^{130}$ These contentions basically pose the problem of coercion of the terminal patient's decision. Coercion ${ }^{131}$ may take the form of subtle pressure from other individuals, unconscious motivations, or simple failures to comprehend information in the form in which it is conveyed. The concern is that coercion of the terminal patient's decision will increase the number and frequency of incorrect decisions by the patient-decisions which are irreversible ${ }^{132}$-imposing societal costs greater than the costs if the responsibility were placed on the individual's family, physicians and the state. If that were the case, it might be argued that the state should override the patient's expressed will. However, the state should avoid coercing an individual to protect him from coercion if some less drastic way of vindicating the state's interests is available. The state can structure its approach so that only patients who are relatively uncoerced may make the ultimate decision as to treatment, striving to assure that the patient makes the decision with genuine understanding ${ }^{133}$ of information material to the decision. Furthermore, even if the issue is a close one, interests in privacy argue that society opt for an approach encouraging selfdetermination; voluntary euthanasia is not espoused simply to alle-

129. Id. at 2-3. The case involved a 60 -year-old with possible breast cancer. At the hearing, she focused on fear of surgery as a reason for refusal. Other witnesses sug: gested that the patient's reasons included, inter alia, the fear that the operation would prevent a movie career.

130. See, e.g., Kamisar, supra note 93, at 991-92, 985-89; Hearings on Dying, supra note 5 , at 26.

131. On the issue of coerced consent, see Shapiro, supra note 76, at 316-20 (coercion to consent in prisons). See generally J. KaTz, Experimentation with Human Beings 609.724 (1972). The fact that the alternative of refusal must be available for consent to be uncoerced was recognized explicitly in the Nuremburg judgments. See 2 Trials of War Criminals Before the NUremburg Military Tribunals 181-83 (1948) (excerpts from "The Medical Case"). See also Relf v. Weinberger, 372 F. Supp. 1196 (D.D.C. 1974) (held Department of Health, Education, and Welfare regulations to be arbitrary and unreasonable since they do not sufficiently protect welfare clients against coercion to agree to sterilization).

132. Kamisar argues that voluntary euthanasia should not be permitted because "the consequence of error is so irreparable," Kamisar, supra note 93, at 1013. Kamisar's point is apparently that the patient may be nonterminal. That the refusal of treatment in a nonterminal situation may result in harm is, however, a part of the price the doctrine of informed consent must pay in order to assure self-determination. The way to reduce possible error is to maximize the supply of accurate information to the decisionmaker (here, the competent patient), not to deprive him of choice.

133. For a recent proposal discussing procedures to assure understanding in the medical context, see Miller and Willner, A Suggestion for Promoting Free and Informed Consent, 290 NEw ENG. J. MED. 964 (1974). Many of the problems of coercion and understanding may be handled by a suitable test for competency. See p. 1653 supra. 
viate pain, ${ }^{134}$ but rather to preserve to the terminal patient his last meaningful freedom, that of control over the time of his death. ${ }^{135}$ If the terminal patient is competent according to the Grannum test, ${ }^{136}$ then he has the same right to self-determination through informed consent as his brethren with more comforting prospects for longevity.

There is evidence that nondisclosure to dying patients is an accepted practice among doctors. ${ }^{137}$ Apparently, a strong feeling exists that a dying patient would be shocked, depressed, or otherwise adversely affected if he were acquainted with the facts, or that he usually knows he is dying anyway. ${ }^{138}$ On the other hand, from the patient's point of view, a majority of Americans want to be able to tell their doctor to let them die if they suffer from an incurable condition. ${ }^{130}$ Furthermore, dignity of the patient, informed consent, and the opportunity to arrange one's affairs dictate that the patient should be told of his condition.

By either ignoring the dying patient's wishes as irrational or failing

134. Alleviation of pain was cited as the only reason for voluntary euthanasia in Kamisar, supra note 93 , at 1008.

135. See Szasz, in Symposium on the Aging Poor, 23 Syracuse L. Rev. 45, 79 (1972); Szasz, Illness and Indignity, 227 J.A.M.A. 543-45 (1974). See also Rudikoff, The Problem of Euthanasia, Commentary, Feb. 1974, at 65: "Advocates of euthanasia do not in fact urge it as public policy, but merely as a possible private alternative which should be removed from the criminal category."

To refuse to permit the dying patient to control his time of death may also work financial and emotional hardship on the patient and his family. If society deprives the competent terminal patient of his right to time his death, then society should reimburse him and his family for the full costs of such deprivation. Commentators suggesting that society has such a right to prolong the death of a terminal patient generally do not view society as owing any reimbursement, apparently due to asserted state interests in preserving life or morals. See generally Kamisar, supra note 93. But cf. Venes \& Huttenlocher, Letter to the Editor, 290 NEw ENG. J. MED. 518 (1974); note 3 supra.

136. See p. 1653 supra.

137. See, e.g., Hackett \& Weisman, Denial as a Factor in Patients with Heart Disease and Cancer, 164 ANNALS N.Y. ACAD. SCI. 802, 805, 808-11 (1969); Euthanasia Questions Stir New Debate, supra note 3, at 73-81. But of. B. Bird, TAlking With Patients 79 (2d ed. 1973). Dr. Bird feels that the trend is to let patients know of their impending death. "[T] he need to assure this right [of the terminal patient to know his condition] seems obvious and there is little argument to be brought against it." However, "[m]any doctors have a dread of death so great they can scarcely function in its presence." Id. at 77. Some efforts are now being made to train physicians to cope with the terminally ill. See, e.g., Artiss \& Levine, Doctor-Patient Relation in Severe Illness, 288 NEw ENG. J. MED. 1210 (1973). Keeping the dying person uninformed about his condition is a relatively recent historical development. In the Middle Ages, it was the clear responsibility of others, particularly physicians, to inform the dying patient, "and for centuries they executed it faithfully." Ariès, Death Inside Out, Hastings Center Studies, May 1974, at 3.

138. See generally E. KüBlER-Ross, supra note 2; cf. Hagman, The Medical Patient's Right to Know, 17 U.C.L.A. L. REv. 758, $778-79$ (1970).

139. See, e.g., Nation Moves Toward Right To Death, 2 Currenr OPINion 39 (1974) (in a Gallup Poll, 52 percent responded "yes" to the question, "When a person has a disease that cannot be cured, do you think doctors should be allowed by law to end the patient's life by some painless means if the patient and family request it?"); HOSP. WEEK, Apr. 27, 1973 (in a Louis Harris poll, 62 percent of those interviewed felt that they should be able to ask their doctor to let them die). 
to inform the patient of his condition in the first place, the issue of competency has often been used by the medical profession to make its own decisions as to what treatment to give terminal patients. ${ }^{140}$ Thus, courts should carefully consider the competency test. Therapeutic privilege should not expand into a presumption of incompetency, with the result of denying to the patient the right to render an informed consent or to make his own decision about euthanasia.

\section{Needed Legislative Changes}

Uncertainty regarding the law of suicide and homicide has prompted many to feel that legislation authorizing some forms of euthanasia is desirable. ${ }^{141}$ Legislation would reduce fears of liability ${ }^{142}$ for complicity in certain forms of voluntary euthanasia by health care providers and thus allow them to honor their patients' wishes.

Originally suicide ${ }^{143}$ was a felony punishable by driving a stake through the body and burying the corpse under a public highway. All of the suicide's property was forfeited to the sovereign. ${ }^{144} \mathrm{~A}$ mellowing $^{145}$ of legal attitudes toward suicide has occurred so that it is

140. There is evidence that the medical profession does engage in passive euthanasia. See Hearings on Dying, supra notc 5, at 34.35 (a doctor testified that he had let hundreds of patients die and that such was the practice of roughly "75 percent of the doctors"). See also Hearings on Dying, supra, at 25; J. KATz, supra note 131, at 692-709 (1972) (collects several articles on the subject); NewsweEk, Jan. 28, 1974, at 43 (a 1969 poll of the Ass'n of Am. Physicians found that 87 percent approved passive euthanasia, and 80 percent admitted having practiced it). Williams desires legislation to recognize this de facto power in the discretion of health care providers. Williams, supra note 99, at 14, 15, 17 .

141. See Hearings on Dying, supra note 5, at 33 (example of bill proposed in Florida permitting passive euthanasia).

142. See Kamisar, supra note 93, at 982.83 n.41. See, e.g., Application of President \&: Directors of Georgetown College, Inc., 118 U.S. App. D.C. 80,89 n.18, 331 F.2d 1000, 1009 n.18, rehearing denied, 118 U.S. App. D.C. 90,331 F.2d 1010, cert. denied, 377 U.S. 978 (1964) ("[d] cath resulting from failure to extend proper medical care, where there is a duty of care, is manslaughter in the District of Columbia"); People v. Roberts, 211 Mich. 187, 178 N.W. 690 (1920) (conviction of murder for making available upon request the poison which dying wife drank); John F. Kennedy Memorial Hosp. v. Heston, 58 N.J. 576, 581-82, 279 A.2d 670, 672-73 (1971) (attempted suicide is a crime in New Jersey). See also Epstein \& Benson, The Patient's Right to Refuse, Hospirals, Aug. 16, 1973, at 41 (safest course of conduct is to turn to courts for guidance in each case of refusal of treatment); Hearings on Dying, supra note 5, at 68-70 (attempts to distingtish "benemortasia"), 80 .

143. See generally Comment, The Punishment of Suicide-A Need for Change, 14 VILL. L. REV. 463 (1969).

144. State v. Campbell, 217 Iowa 848, 850, 251 N.W. 717, 718 (1933); Burnett v. People, 204 III. 208, 221, 68 N.E. 505, 510 (1903). In 1824, the English rule mellowed so that the suicide's body could be buried in a churchyard, but only between 9:00 and 12:00 p.m. and without religious ceremonies. State v. Willis, 255 N.C. 473, 475, 121 S.E.2d 854, 855 (1961).

145. Cf. Hearings on Dying, supra note 5, at 5; Boeth, Now, a Right to Suicide?, NEWSWEEK, Oct. 29, 1973, at 78, 83 . 
no longer a crime in some jurisdictions; ${ }^{148}$ however, in a few others, suicide remains a felony or misdemeanor. ${ }^{147}$ Some have argued that it is proper to forbid suicide because every life has value to society and may not be taken even by self-destruction. ${ }^{148}$ This argument suggests that the cost of the suicide of an individual is too great in terms of lost productive potential and psychological damage to other persons in society. However strong the argument with respect to suicide in general, it merits close scrutiny in the voluntary euthanasia situation.

Three basic scenarios are presented. First, there is the case of the dying patient refusing treatment but for whom no treatment could effect a recovery. This patient has little in terms of productive potential to offer society. Though third parties might suffer disutility ${ }^{140}$ from a decision to refuse treatment, this psychological loss is presumably minimal since the patient is competent, voluntarily making the decision, and would die relatively soon anyway. Further, commitment to self-determination and privacy presupposes a disposition to permit activities whose adverse impact on others is only psychological. ${ }^{150}$ Since the opportunity to refuse treatment may be very important to many patients, ${ }^{151}$ deprivation of this choice may be a considerable cost that is not outweighed by the adverse psychological impact on others.

Second is the case of a dying patient who could recover but refuses treatment. The primary example is that of an individual who refuses on religious grounds. This patient presumably does have productive potential for society. However, this society, generally committed to a free market economy, normally refrains from compelling individuals to maximize their productive potential; indeed, there are instances

146. See, e.g., Stiles v. Clifton Springs Sanitarium Co., 74 F. Supp. 907, 909 (W.D.N.Y. 1947) (suicide not a crime but is a great public wrong; case applied $\$ 2301$ of N.Y. Penal Law of 1909 which was repealed by N.Y. Penal LAw \$ 500.05 (McKinney 1967)); Tate v. Canonica, 180 Cal. App. 2d 898, 903, 5 Cal. Rptr. 28, 33 (1960) (suicide not a crime in California); American Motorcycle Ass'n v. State Police, 11 Mich. App. 351, 359,158 N.W.2d 72, 76 (1968) (suicide neither a statutory nor common law crime in Michigan); Hundert v. Commercial Travelers' Mut. Accident Ass'n of Am., 244 App. Div. 459, 460, 279 N.Y.S. 555,556 (1935).

147. See, e.g., State v. Willis, 255 N.C. $473,476,121$ S.E.2d 854, 856 (1961) (suicide is a crime, probably a misdemeanor); State v, Levelle, 34 S.C. 120, 131, 13 S.E. 319, 321 (1891) (case interprets what is now S.C. CODE ANN. \$ 17-122 (1962) as retaining the common law character of felony for suicide).

148. See, e.g., Bisenius v. Karns, 42 Wis. 2d 42, 52, 165 N.W.2d 377, 382, appeal dismissed, 395 U.S. 709 (1969) ("protection of the safety of all . . . against the consequences of their own actions is a legitimate use of the police powers of the state").

149. The disutility takes the form of psychological insecurity if the refusal of treatment is perceived as derogatory of life. The insecurity may be a manifestation of the denial of death, see p. 1647 supra.

150. See, e.g., Roe v. Wade, 410 U.S. 113, $152-56$ (1973). See also notes 86.88 supra. The textual statement does not imply any established rule or principle uniformly applied.

151. See notes 124 \& 139 supra. 
where it encourages considerable waste of productive potential. ${ }^{152}$ Thus, an individual decision to cease productive contribution to society does not support abridging a patient's right to refuse treatment. Any psychological harm to others must be balanced against commitments to religious freedom, ${ }^{153}$ as well as interests in privacy and self-determination. ${ }^{15 t}$ Again, deprivation of patients' choices may be at such considerable cost as to overcome adverse psychological impact on others.

Finally, there is the problem of the dying patient who requests active rendition of a death-inducing agent. The opportunity to obtain active euthanasia increases the choices available to a competent patient and may reduce his costs by allowing him to select such a procedure if it maximizes his satisfaction. Certainly active rendition could eliminate considerable suffering during a prolonged and irreversible dying process. The suffering may impose substantial costs not only on the patient but on his family and health care providers as well. However, active euthanasia generally involves the participation of an identifiable third party in its provision. Such participation may be at considerable psychological cost to the third party and to society. Hence, as long as a third party is heavily involved, the argument is stronger for society to forbid voluntary active euthanasia. ${ }^{155}$

A strong argument often advanced for prohibiting suicide is that decisions for self-destruction are not firmly held and may be only pleas for help. ${ }^{158}$ However, there is evidence that many people who

152. See, e.g., J. Galbraith, Economics and the Public Purpose 31-37, 58-60, 234-38 (1973) ("crypto-servant" role of women).

153. See, e.g., In re Osborne, 294 A.2d 372 (D.C. App. 1972).

154. Erickson v. Dilgard, 44 Misc. 2d 27, 252 N.Y.S.2d 705 (Sup. Ct. 1962).

155. Third party involvement and consequent psychological costs have been minimized in some plans for rendition of active euthanasia. It has been suggested that third parties be permitted to place poison beside a dying patient on request of the patient. The patient would administer the poison to himself. "Switzerland permits the doctor to put poison in the hand of the patient but not actually to administer it himself." Rudikoff, supra note 135 , at 62 . Apparently a similar situation existed in Texas until January 1, 1974. See note 165 infra. This position decreases involvement of third parties, for the final art is performed solely by the patient. Indeed, the third party involvement seems akin to "unplugging" a life support apparatus which had been sustaining the patient.

Of course, the political feasibility of even voluntary passive euthanasia legislation is questionable. Oregon State Senator Hoyt, a sponsor of House Bill 2997 (legalizing passive euthanasia) in the 1973 session of the Oregon legislature, has concluded that euthanasia legislation is not politically possible: "Legislation has to follow public opinion, it cannot lead it ...." He has decided "reluctantly to take the subject out of the political arena and depend on social education." Letter from State Senator C.R. Hoyt to Charles H. Montange, Mar. 20, 1974 (copy on file with the Yale Law Journal). Senator Hoyt also notes that espousal of etrthanasia "is a definite political liability."

156. This may indeed be true of certain classes of individuals. Patel, Pathology of Suicide, 13 MíD., Scr. \& L. 103, 104 (1973). 
take their own lives do so with determination and conviction. ${ }^{157}$ This observation logically applies with special force to dying patients seeking a form of euthanasia, and consequently the sanction against suicide is less defensible when applied to this group. ${ }^{158}$ Thus, policies prohibiting suicide might be limited to apply only to nonterminal cases. Alternatively, definitions could be changed to make clear that voluntary passive euthanasia is not suicide.

The issue of liability for euthanasia has seldom reached the courts. ${ }^{150}$ Perhaps this is due to prosecutorial discretion, ${ }^{100}$ but it is more likely due to difficulty of proof, ${ }^{101}$ or simply to failure of authorities to discover the situation. ${ }^{162}$ Nonetheless, dictum in some jurisdictions indicates that complicity in active euthanasia even by a well-intentioned physician would constitute sufficient malice for a murder prosecution. ${ }^{163}$ In others, statutes indicate that assistance in euthanasia amounts to the crime of aiding and abetting suicide. ${ }^{164}$ In still others, in the absence of a specific statute regarding aiding suicide, such assistance may be murder, manslaughter, or no violation of the law. ${ }^{105}$ Passive euthanasia provides a more difficult problem; commentators

157. Id. at 104-05. The study found that suicides in elderly age groups were neither insane nor mentally abnormal; rather they made determined attempts due to the loss of a loved one or because of physical or social calamity.

158. There is authority suggesting the anti-suicide sanctions should apply to individuals seeking euthanasia for religious purposes. See Application of President \& Directors of Georgetown College, Inc., 118 U.S. App. D.C. 80, 89 n.18, 331 F.2d 1000, 1009 n.18, rehearing denied, 118 U.S. App. D.C. 90, 331 F.2d 1010, cert. denied, 377 U.S. 978 (1964) (Jehovah's Witness given blood transfusions to save her life over objections by herself and her family).

159. American and British law apparently record only two prosecutions of physicians for murdering dying patients. Euthanasia Questions Stir New Debate, supra note 3, at 73.

160. Kamisar, supra note 93 , at 971 .

161. See Williams, supra note 93 , at 15 (morphine is an easily disguised death. inducing agent). See also N.Y. Times, Jan. 29, 1974, at 66, col. 2 (morphine sulfate could reduce one "to a terminal status very rapidly").

162. See Parry-Jones, supra note 99.

163. People v. Conley, 64 Cal. 2d 310, 322, 411 P.2d 911, 918, 49 Cal. Rptr. 815, 822 (1966) (Traynor, J., dictum: "[O]ne who commits euthanasia bears no ill will toward his victim and believes his act is morally justified, but he nonetheless acts with malice if he is able to comprehend that society prohibits his act regardless of his personal belief").

164. See, e.g., English Suicide Act of 1961, $9 \& 10$ Eliz. 2, c. 60 (suicide no longer a crime but aiding and abetting it is); N.Y. PENAL LAw $\$ \$ 120.30$ (promoting suicide attempt is a felony), 125.15 (manslaughter) (McKinney 1967); PA. STAr. ANN. tit. 18, $\$ 2505$ (b) (1973).

165. Persampieri v. Commonwealth, 343 Mass. 19, 175 N.E.2d 387 (1961) (manslaughter); People v. Roberts, 211 Mich. 187, 178 N.W. 690 (1920) (murder). The Texas position prior to January 1,1974, was that since suicide was not criminal in the state, "one who has aided or abetted suicide is innocent of any violation of law." 53 TEXAs JURISPRUDENCE 528-29 (2d ed. 1964). Aiding or attempting to aid suicide in Texas is now a statutory crime. Tex. Penal Code art. 22.08 (Vernon's 1974). Texas was possibly the only state which viewed aiding suicide as noncriminal absent a statute. Comment, supra note 142, at 474. However, in the absence of a statute, other states are presumably not precluded from adopting the old Texas common law view. 
disagree as to whether the law will attach criminal liability. ${ }^{166}$ But since the line between passive and active euthanasia is somewhat arbitrary, ${ }^{107}$ many cases of passive euthanasia are under the cloud of potential criminal or civil liability. ${ }^{108}$ One would expect rational decisionmaking and more deference to the wishes of patients if the risk of liability were removed.

There remain two final objections which should be faced. It is asserted ${ }^{169}$ that if voluntary euthanasia is now permitted, soon involuntary euthanasia of perceived misfits will be legalized and common. However, this argument does not recognize the gulf that separates voluntary euthanasia and involuntary euthanasia, ${ }^{170}$ a gulf defined by the doctrine of informed consent. Limiting legal euthanasia to cases involving terminal patients who give an informed consent to the procedure supplies a line of sufficient clarity to prevent the imposition of mercy killing on nonconsenting terminal patients.

The second and more pragmatic objection is that even if the principle of euthanasia were accepted, specific plans for euthanasia are unworkable: ${ }^{171}$ The plans either restrict the availability of their provisions or unduly bureaucratize the sick room in order to provide the necessary safeguards. Certain plans undoubtedly have this effect, since they require long waiting periods between request for euthanasia and its rendition, ${ }^{172}$ or introduce a new agent into the hospital to represent the dying patient to his family, doctor, and associates. ${ }^{173} \mathrm{An}$ alternative approach is the "living will," a document executed by the patient while healthy which purports to specify when treatment may be terminated when the individual becomes critically ill. ${ }^{174}$ Unfortu-

166. Compare Cantor, supra note 5, at 258-64, with Kamisar, supra note 93, at 982 n.41. See also Hearings on Dying, supra note 5, at 68-70, 89; cf. Fletcher, supra note 99, at 1008 (withdrawal of treatment analyzed as omission so as not to import liability for homicide).

167. See Cantor, supra note 5, at 261. See also Williams, supra note 99, at 21 (act versus omission).

168. See, e.g., Kennedy, supra note 15 (case report of a euthanasia resulting in civil action for wrongful death).

169. See Kamisar, supra note 93, at 1014. See also M. Mannes, LAST Rights 101-05

(1974); Kutner, supra note 5 , at $545-46$.

170. See Cantor, supra note 5 , at 261.

171. See Kamisar, supra note 93 , at 978.

172. See Morris, supra note 5 , at 266-71.

173. See Sullivan, supra note 90 , at 212. See also Note, supra note 16 , at 689 .

174. See Kutner, supra note 5. A copy of a model living will prepared by the Euthanasia Education Council is reprinted in Hearings on Dying, supra note 5, at 141 . The Connecticut State Medical Society has prepared a living will which was rejected by the AMA. See Report 8 of the AMA Judicial Council at the AMA Clinical Conv. in Anaheim, Cal., Dec. 2.5, 1973. E. Howard, Actions Taken by the AMA House of Delegates, Dec. 17, 1973, at 31. The Connecticut document is reprinted in Ramsey, The Indignity of 'Death with Dignity,' Hastings Center Studies, May 1974, at 47, 52. 
nately, most living wills are so vague that they offer little confidence in the adequacy of safeguards for euthanasia under their aegis. ${ }^{175}$ The scheme which this Note suggests does not involve great complexity or bureaucratization. The terminal patient, like the nonterminal patient, is entitled to refuse treatment. ${ }^{178}$

\section{Conclusion}

The individual's right to self-determination over his own body is frequently asserted as the axiomatic foundation of informed consent. Recent informed consent cases abolishing the medical community standard rule for disclosure have returned to a position of greater consistency with the Schloendorff axiom. It is fundamental to the doctrine that a right to consent presupposes a right to refuse. Hence, if courts take informed consent seriously, they must recognize the right of a competent terminal patient to forego treatment.

Countervailing concerns about the psychological impact of refusals of treatment upon society are not strong enough to overcome the law's commitment to decisionmaking by the individual with respect to his own medical treatment. Society's interests in minimizing incorrect decisions may be met by proper tests for competency and by measures to assure sufficient comprehension of relevant material information. The outcome remains the same: recognition of the patient's right to refuse, whether the patient is terminal or not. ${ }^{177}$ Through application of developing tort doctrine, the courts alone might achieve this result. However, legislation which dispels the fear of possible criminal liability in cases of voluntary euthanasia is desirable. Lawmakers should mitigate the uncertainties and generate adequate legal measures to permit a dignified death.

175. Living wills might be individually tailored to mitigate some of the uncertainties as to actual intent under particular circumstances, and also to display thorough comprehension of the document signed. See Modell, $A$ "Will" to Live, 290 NEW ENG. J. MED. 907, 908 (1974).

176. See, e.g., Erickson v. Dilgard, 44 Misc. 2d 27, 252 N.Y.S.2d 705 (Sup. Ct. 1962).

177. This outcome is apparently consistent with the desires of the majority of Americans. See notes 124 \& 139 supra. 